NBSIR 82-2522

\title{
A Comparison of Unglazed Flat Plate Liquid Solar Collector Thermal Performance Using the ASHRAE Standard 96-1980 and Modified BSE Test Procedures
}

U.S. DEPARTMENT OF COMMERCE National Bureau of Standards National Engineering Laboratory Center for Building Technology

Building Equipment Division

Washington, DC 20234

May 1982

Sponsored by:

Division of Active Heating and Cooling - ce of Solar Heat Technologies - QC Department of Energy

100 hington, DC 20585 



\section{A COMPARISON OF UNGLAZED FLAT PLATE LIQUID SOLAR COLLECTOR \\ THERMAL PERFORMANCE USING THE \\ ASHRAE STANDARD 96-1980 AND \\ MODIFIED BSE TEST PROCEDURES}

John P. Jenkins and Kent A. Reed

U.S. DEPARTMENT OF COMMERCE

National Bureau of Standards

National Engineering Laboratory

Center for Building Technology

Building Equipment Division

Washington, DC 20234

May 1982

Sponsored by

Division of Active Heating and Cooling

Office of Solar Heat Technologies

U.S. Department of Energy

Washington, DC 20585

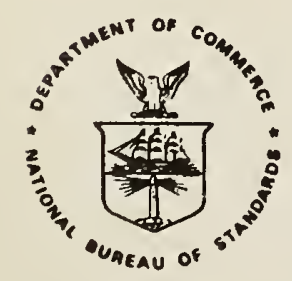

U.S. DEPARTMENT OF COMMERCE, Malcolm Baldrige, Secretary NATIONAL BUREAU OF STANDARDS, Ernest Ambler, Director 



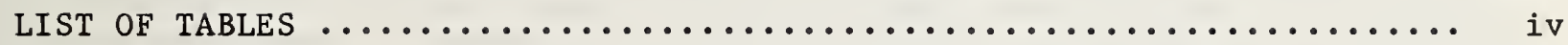

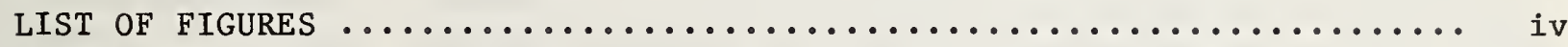

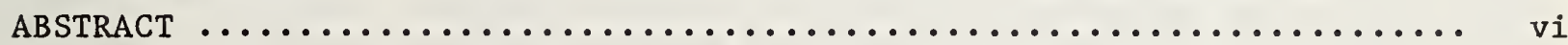

1. Introduction $\ldots \ldots \ldots \ldots \ldots \ldots \ldots \ldots \ldots \ldots \ldots \ldots \ldots \ldots \ldots \ldots \ldots \ldots \ldots \ldots$

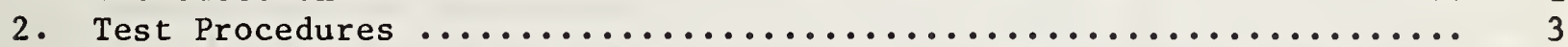

3. Uncertainty Associated With Unglazed Collector Efficiency Results .. 8

4. Test Facility .................................. 9

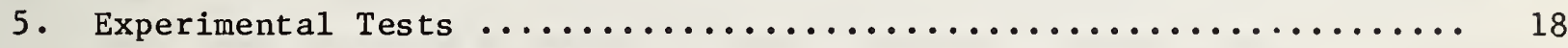

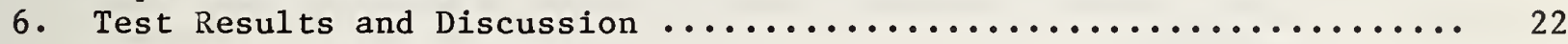

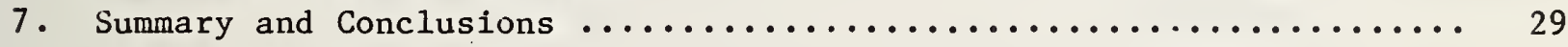

8. References .................................... 30 


\begin{abstract}
This paper reviews the BSE procedure and summarizes the ASHRAE Standard 96-1980 for testing unglazed solar collectors. The ASHRAE procedure consists exclusively of outdoor testing, whereas the BSE procedure requires a combination of outdoor and indoor testing (no irradiation) to determine the collector optical and thermal loss characteristics, respectively. Two unglazed flat plate liquid solar collectors were tested according to ASHRAE Standard 96-1980 and BSE procedures and the results compared. During the indoor BSE thermal loss tests blowers were used to simulate winds of $0-3.9 \mathrm{~m} / \mathrm{s}$ $(0-8.72 \mathrm{mi} / \mathrm{hr})$ to investigate the wind effect upon collector thermal losses. The results demonstrate that the differences between the BSE and ASHRAE Standard 96-1980 thermal efficiency curves were less than the uncertainty associated with the curves.

Key Words: ASHRAE Standard 96-1980; BSE; collector efficiency; unglazed collector
\end{abstract}




\section{INTRODUCTION}

In January 1980 the American Society of Heating, Refrigeration, and AirConditioning Engineers adopted ASHRAE Standard 96-1980, "Methods of Testing to Determine the Thermal Performance of Unglazed Flat Plate Liquid-Type Solar Collectors" [1]*. Standard 96-1980, which closely parallels ASHRAE Standard 93-77 [2], defines test procedures for determining the instantaneous thermal efficiency and incident angle modifier for unglazed solar collectors. Standard 96-1980, like 93-77, allows testing either outdoors in natural sunlight or indoors under a solar simulator while requiring the establishment of quasi-steady-state test conditions under high levels of "clear sky" radiation. Because of the greater sensitivity of unglazed collectors to environinent conditions and high operating flow rates, Standard 96-1980 in contrast to 93-77 imposes substantially tighter requirements on collector test loop thermal stability, instrumentation accuracy, and allowable environmental variations during a test.

In May 1978, a German industrial working group entitled Bundesverband Solarenergie (BSE), completed and adopted, "Guidelines and Directions for Determining the Usability of Solar Collectors" [3] . Part A of the Guidelines defines test procedures for determining the thermal performance of solar collectors. Unlike the ASHRAE procedures, the BSE procedure requires both outdoor (irradiated) and indoor (nonirradiated) testing in order to determine independently the collector optical efficiency and thermal loss characteristics, respectively. From these separately determined collector properties, instantaneous thermal performance is calculated for the operating conditions expected.

The BSE collector test procedure can potentially reduce the time required for testing and improve the reproducibility of collector test results, compared to the ASHRAE outdoor test procedures, without requiring an indoor solar simulator as specified in the ASHRAE standard. However, the BSE procedure determines the collector heat loss, under zero-irradiance conditions, and it is not apparent that the thermal efficiency established by the BSE procedure will be equivalent to the thermal efficiency determined by the ASHRAE procedures.

In an earlier study conducted at the National Bureau of Standards $[4,5]$, five glazed flat plate water-heating collectors were tested according to both the BSE procedure and the ASHRAE Standard 93-77 outdoor procedure, and the results were compared. For each of the five collectors tested, the instantaneous thermal efficiency curves determined by the two procedures differed by less than the total uncertainties associated with the curves. This agreement of the test results was substantiated by a concurrent analytical study that also investigated the influence of various collector and environmental parameters on the residual differences [6].

* Numbers in brackets indicate references in section 8 . 
In the current study, two representative unglazed flat plate water-heating collectors were tested according to both a modified BSE procedure and the new ASHRAE Standard 96-1980 outdoor procedure. This report describes the salient features of the procedures, the test apparatus, and the test results. 


\section{TEST PROCEDURES}

\section{ASHRAE Standard 96-1980}

The ASHRAE Standard 96-1980 test requirements for stability, accuracy, and environmental conditions exceed those of ASHRAE Standard 93-77. On1y the salient features and differences are described here. According to ASHRAE Standard 96-1980, if the collector to be tested has no back insulation, it is to be mounted on a rigid insulating board having an insulating value of $R=$ $0.88 \mathrm{~m}^{2} \mathrm{C} / \mathrm{W}\left(5.0 \mathrm{ft}^{2} \cdot \mathrm{h} \cdot \mathrm{F} / \mathrm{Btu}\right)$. The irradiance in the plane of the collector must exceed $630 \mathrm{w} / \mathrm{m}^{2}\left(200 \mathrm{Btu} / \mathrm{ft}^{2} \cdot \mathrm{h}\right)$ and for near-normal-incidence testing the angle of incidence must be less than $30^{\circ}$. The average wind speed for each test condition must not exceed $1.3 \mathrm{~m} / \mathrm{s}(3.0 \mathrm{mph})$, a factor of three tighter than the ASHRAE Standard 93-77 requirement. The range of ambient temperature for all reported test points making up the efficiency curve must be less than $10^{\circ} \mathrm{C}\left(18^{\circ} \mathrm{F}\right)$, again a factor of three less than the ASHRAE Standard 93-77 requirement. In addition, the allowable ambient temperature is explicitly restricted to the range of 15 to $38^{\circ} \mathrm{C}\left(60\right.$ to $\left.100^{\circ} \mathrm{F}\right)$.

The instrumentation specifications for an ASHRAE Standard 96-1980 test follow closely those of ASHRAE Standard 93-77, with two exceptions. The limits for accuracy and precision in the temperature difference measurements are now $\pm 0.01^{\circ} \mathrm{C}\left( \pm 0.018^{\circ} \mathrm{F}\right)$, a factor of ten lower. In addition, ASHRAE Standard 96-1980 calls for measurement of the dew point temperature for each data point.

The more restrictive temperature requirements are reflected in the apparatus specification of ASHRAE Standard 96-1980 as we11. Piping and mixing section losses or gains at collector inlet and outlet must not cause a temperature change for any test of more than $0.01^{\circ} \mathrm{C}\left(0.018^{\circ} \mathrm{F}\right)$ between each mixing device and the collector. The reconditioning apparatus must control the temperature of the fluid entering the collector to within $\pm 0.1^{\circ} \mathrm{C}\left( \pm 0.18^{\circ} \mathrm{F}\right)$ for each data point. Both specifications are around a factor of five more restrictive than their ASHRAE Standard 93-77 counterparts.

In the ASHRAE Standard 96-1980 procedure, the collector thermal efficiency curve for near-normal-incidence is established by taking at least four data points at each of four different values of inlet fluid temperature. The ordinate of each data point is the efficiency which is calculated as the average thermal energy delivered by the collector during a test interval divided by the average total solar irradiation incident upon the gross collector area during a test interval. The thermal efficiency data are plotted against the fluid parameter $\left(t_{f, i}-t_{a}\right) / G$, where $t_{f, i}$ is the inlet fluid temperature, $t_{a}$ is the ambient air temperature, and $G$ is the solar irradiance measured in the plane of the collector. At least one reported value of the fluid parameter must be in the negative range of approximately -0.02 to $-0.15 \mathrm{~m}^{2}{ }^{\circ} \mathrm{C} / \mathrm{W}\left(-.11\right.$ to $\left.-.84^{\circ} \mathrm{F} \mathrm{hr} \mathrm{ft}^{2} / \mathrm{Btu}\right)$. This major departure from the ASHRAE Standard 93-77 procedure is dictated by the fact that unglazed collectors are normally used in low temperature applications in which the collector fluid may be below ambient air temperature resulting in heat gains as well as solar heat gains. An equation for the thermal efficiency curve 
is obtained from the data using the least-square fitting technique. A typical ASHRAE Standard 96-1980 test result including the data and the fitted thermal efficiency curve is shown in figure 1.

The experimental determination of the incident angle modifier for an unglazed collector follows closely the ASHRAE Standard 93-77 procedure and so will not be described here.

ASHRAE Standard 96-1980 does not require the determination of a collector time constant.

\section{Modified BSE Procedure}

The derivation and application of the BSE collector test procedure has been described in detail previously $[4,5]$. The essence of the method is the separate determination of the collector optical efficiency (a number), . no, during outdoor testing, and the collector thermal loss (a function), $Q_{L}$, during indoor testing. The collector thermal efficiency, $n$, is then calculated by

$$
n=n_{0}-\dot{Q}_{L} /\left(G \cdot A_{n}\right) \text {, }
$$

where $G$ is the total solar irradiance measured in the collector plane and $A_{n}$ is the net aperture area to the collector. For the purpose of comparison within this study, the BSE procedure was modified to use gross collector area instead of aperture area, in conformance with ASHRAE Standard 96-1980.

The collector optical efficiency is determined in the BSE procedure by measuring thermal efficiency under conditions where collector thermal losses are minimized. Specifically, for a valid data point, the mean temperature of the fluid in the collector, $\mathrm{t}_{\mathrm{m}}$, defined by

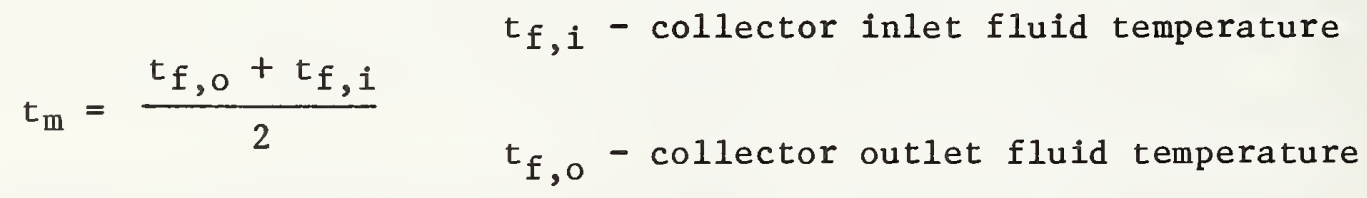

must be held within $\pm 10^{\circ} \mathrm{C}\left(18^{\circ} \mathrm{F}\right)$ of the ambient air temperature, $t_{a}$. The measured thermal efficiency is then equal to the optical efficiency, $n_{0}{ }^{*}$ When the mean fluid temperature cannot be held within $\pm 10^{\circ} \mathrm{C}$ of ambient air temperature, then the measured thermal efficiency must be corrected for collector thermal losses to arrive at the optical efficiency. The appropriate correction must be calculated for the actual value of $\left(t_{m}-t_{a}\right)$ based on the measured indoor thermal losses.

Using the BSE procedure, collector thermal losses are determined under essentially zero $\left(<1 \mathrm{~W} / \mathrm{m}^{2}\right)$ solar irradiation conditions within a controlled indoor environment. The environmental test conditions must be regulated so that the air temperature remains between 15 and $25^{\circ} \mathrm{C}\left(59-77^{\circ} \mathrm{F}\right)$ while the wind speed 7 to $9 \mathrm{cn}(2.75-3.5$ in) above the collector surface is greater than $4 \mathrm{~m} / \mathrm{s}(8.9 \mathrm{mi} / \mathrm{hr})$. 


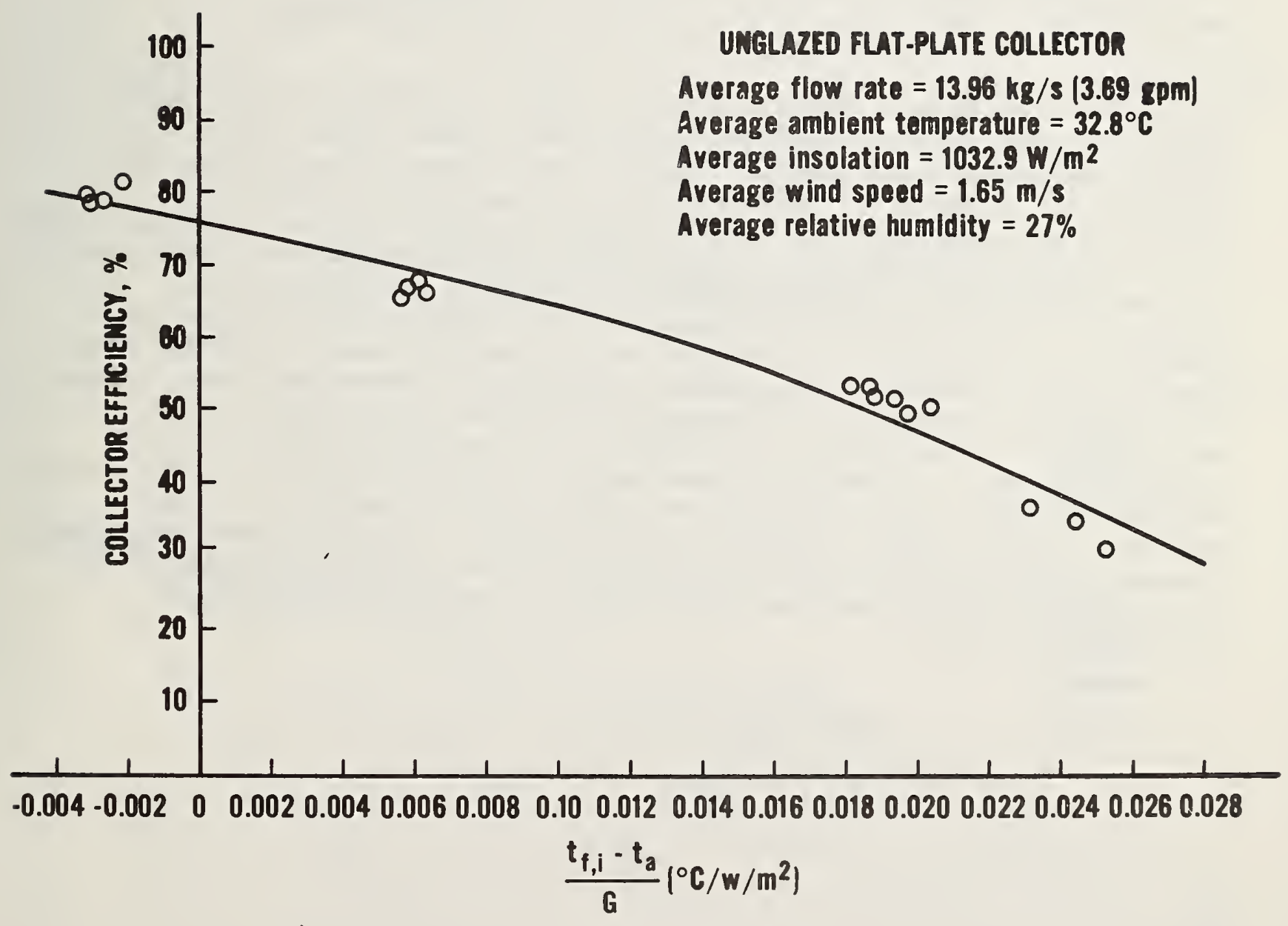

Figure 1. ASHRAE Standard 96-1980 collector efficiency versus the difference between the inlet fluid temperature, $t_{f, i}$, and ambient air temperature, $t_{a}$, divided by the incident solar irradiance $G$. 
In addition, the apparent environmental radiance temperature* or effective black body sky temperature must not deviate from the air temperature by more than $\pm 3 \mathrm{~K}\left(5.4^{\circ} \mathrm{R}\right)$. Preconditioned fluid is circulated through the collector over a range of operating temperatures above ambient, specifically at $\left(t_{\mathrm{m}}-t_{\mathrm{a}}\right)$ values of $30,50,70$, and $90^{\circ} \mathrm{C}\left(86,122,158,194^{\circ} \mathrm{F}\right)$. The thermal loss, $Q_{L}$ is calculated based on the measured fluid flow rate temperature drop between the collector inlet and outlet. The heat loss is then plotted as a function of the parameter $\left(t_{\mathrm{m}}-\mathrm{t}_{\mathrm{a}}\right)$ as shown in figure 2. The equation of the heat loss curve can be obtained using the least-square fitting technique.

A family of collector thermal efficiency curves is constructed from the optical efficiency, $n_{0}$ and the thermal loss function $Q_{L}$, using equation 1. The curves are calculated for irradiance values of $200,400,600,800$, and $1000 \mathrm{~W} / \mathrm{m}^{2},\left(63.7,126,190,253,317 \mathrm{Btu} / \mathrm{hr} \mathrm{ft}{ }^{2}\right)$ and plotted as a function of the parameter $\left(t_{m}-t_{a}\right)$ as shown in figure 3 .

For the purpose of this comparative study minor modifications have been introduced into the BSE procedure to allow for direct comparison between the BSE and ASHRAE test results. As mentioned already, the BSE procedure was modified to use gross collector area instead of net aperture area. The same test facility built for the ASHRAE Standard 96-1980 testing was used for the BSE testing, so that the more restrictive instrumentation and apparatus specifications in ASHRAE Standard 96-1980 were met automatically. The collector thermal. losses were measured over a range of $\left(t_{m}-t_{a}\right)$ from about $-10^{\circ} \mathrm{C}\left(-14^{\circ} \mathrm{F}\right)$ to about $40^{\circ} \mathrm{C}\left(104^{\circ} \mathrm{F}\right)$. As in the development of ASHRAE Standard 96-1980, operating temperatures below ambient temperature were included to investigate the ability of unglazed collectors to gain energy from the environment. The wind speed specification in the BSE procedure was also changed. Because the simulated wind could be controlled easily in the laboratory, collector thermal losses were investigated at several wind speeds from $0 \mathrm{~m} / \mathrm{s}$ (still air) to $3.9 \mathrm{~m} / \mathrm{s}(0-8.72 \mathrm{mi} / \mathrm{hr}$ ). The BSE thermal performance results have been presented within an ASHRAE Standard 96-1980 format. The $t_{m}-t_{a} x$-axis variable has been transposed into the $\operatorname{ASHRAE}\left(t_{f, i^{-}} t_{a}\right) / G$ as discussed in [4].

* Temperature of a perfectly black environment that would radiate the same amount of thermal radiation as the real environment. 


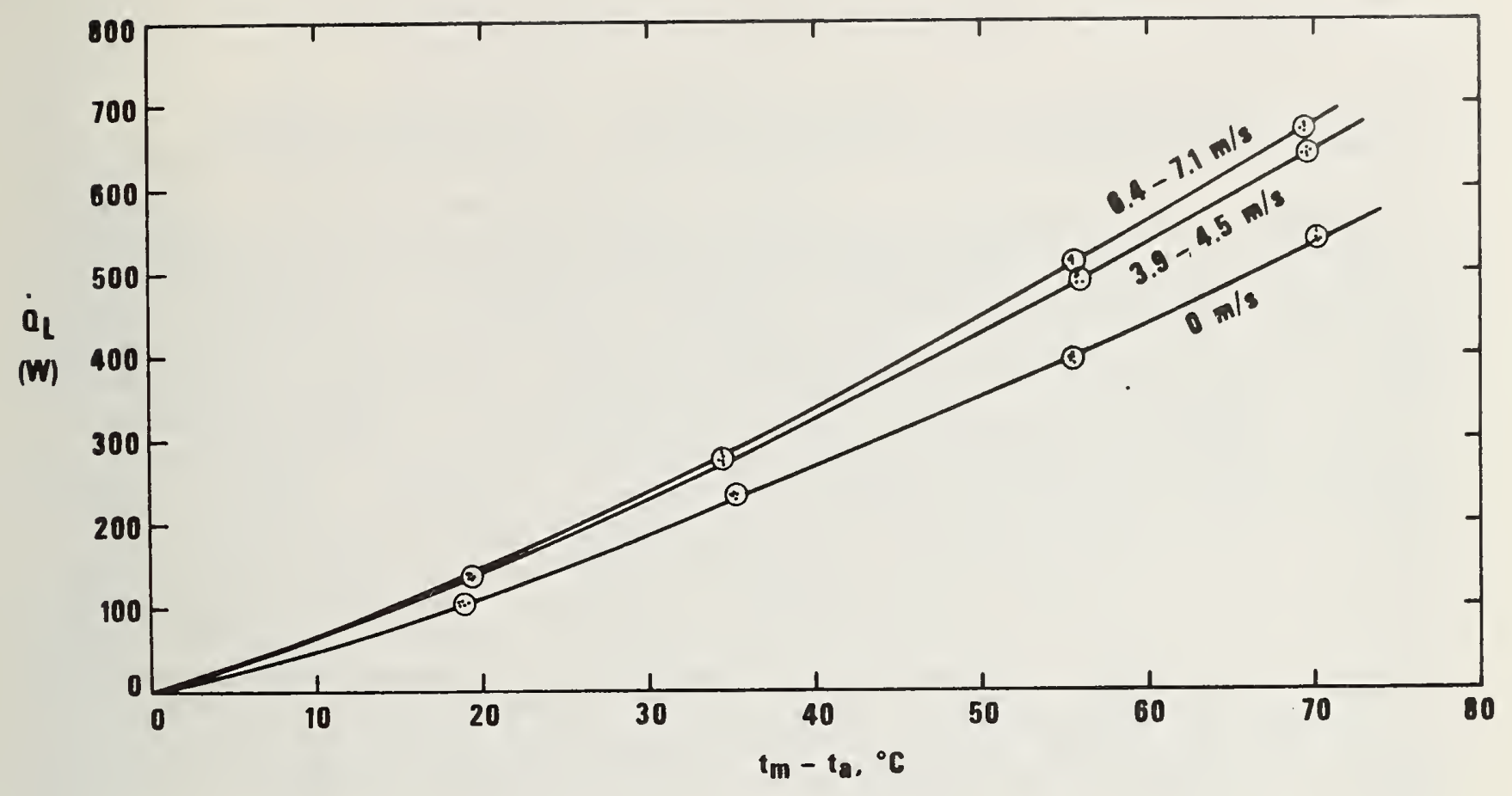

Figure 2. BSE collector thermal losses versus the difference between collector mean fluid temperature, $t_{m}$, and ambient temperature, $t_{a}$.

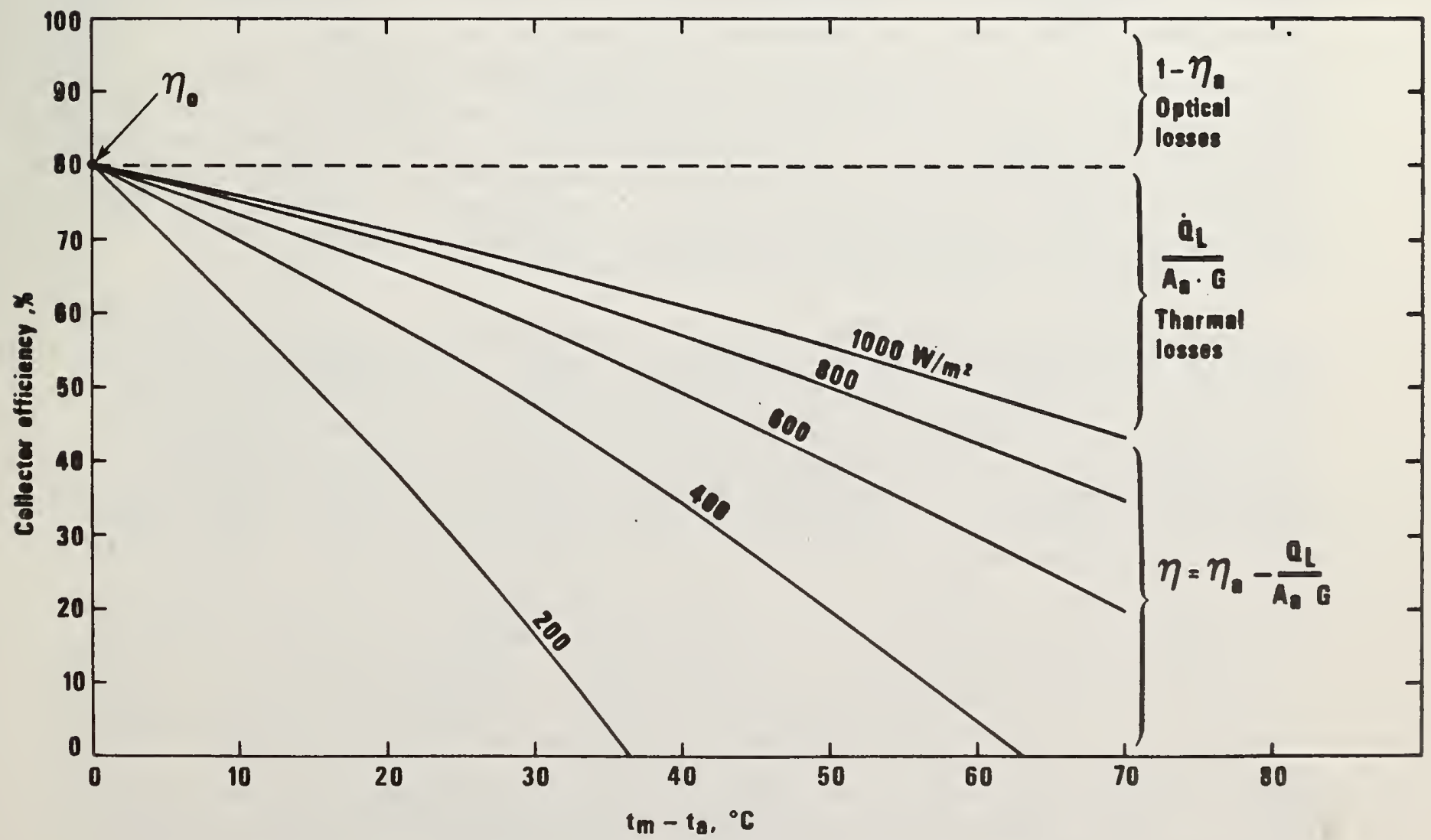

Figure 3. BSE collector efficiency versus the difference between collector mean fluid temperature, $t_{m}$, and ambient air temperature, $t_{a}$. 


\section{UNCERTAINTY ASSOCIATED WITH UNGLAZED COLLECTOR EFFICIENCY RESULTS}

For unglazed collectors, variations in environmental test conditions contribute a large uncertainty in determining collector efficiency that is difficult to quantify. Wind is the dominant environmental parameter. In order to minimize the influence of wind in outdoor thermal performance testing, the ASIRAE Standard 96-1980 requires that the average wind speed during any valid test interval not exceed $1.35 \mathrm{~m} / \mathrm{s}(3.0 \mathrm{mi} / \mathrm{hr})$. If wind were a steady-state phenomenon, this wind speed restriction would be sufficient. For common unglazed flat plate collectors, the uncertainty due to the allowable range of wind speeds could be calculated. Unfortunately, wind is a dynamic phenomenon with continual, transient fluctuations in both magnitude and direction. The short-terï fluctuations strongly influence the collector's instantaneous heat loss coefficient. Because it has not been possible to adequately characterize and correct for wind fluctuations during testing, the resulting thernal performance data exhibit apparently random scatter that increases with increasing $\left(t_{f, i}-t_{a}\right) / G$. At high values of $\left(t_{f, i^{-}} t_{a}\right) / G$ it is even possible for wind fluctuations to preclude establishwent of quasi-steady-state test conditions although the average wind speed stays within the $1.35 \mathrm{~m} / \mathrm{s}(3.0 \mathrm{mi} / \mathrm{hr}) \mathrm{specifi-}$ cation.

The sinulated wind generated during indoor testing is both steady-state and reproducible. As a consequence, the indoor thermal loss data obtained using the modified BSE procedure exhibit minimal scatter due to wind fluctuations. There is, therefore, little uncertainty introduced into the resulting thermal efficiency curves.

The contribution to the uncertainty in collector thermal efficiency due to the propagation of random measurement uncertainties was analyzed for the BSE and the ASHRAE Standard 93-77 test procedures in [4]. The relative uncertainties in measurement are very similar in the case of ASHRAE Standard 96-1980, so the previous analysis is expected to apply. The analysis concluded that the randon measurement uncertainty is typically \pm 4 efficiency points $(n \pm 4)$ for both the ASHRAE and the BSE efficiency curves.

The total uncertainty in unglazed collector thermal performance is a combination of the ineasurement uncertainty and the uncertainty associated with environmental test conditions. Since the BSE thernal loss tests are deterained under stable controlled environmental conditions, the total uncertainty associated with the BSE efficiency curve is essentially linited to the measurement uncertainty of \pm 4 efficiency points. The total uncertainty associated with the ASHRAE therial efficiency curve is expected to be larger. This point is discussed further in section 6 , Test Results and Discussion. 


\section{TEST FACILITY}

The unglazed collector test facility is shown in figures 4-9. The facility comprises a test stand, a fluid test loop, and data acquisition equipment. The entire facility is mounted upon an elevator which is capable of transporting the equipment between indoor and outdoor test facilities. This unique arrangement allows tests to be completed indoors and outdoors using the same test equipment and without disturbing the collector undergoing test. The test stand supports the test collector at any orientation, and contains the fluid test loop. The collector mounting surface consists of asphalt shingles over $1.2 \mathrm{~cm}$ ( $1 / 2 \mathrm{in})$ plywood sheathing backed by fiberglas batts $10 \mathrm{~cm}$ ( $4 \mathrm{in}$ ) thick simulating an actual roof surface.

Fluid Test Loop

The fluid test loop is shown schematically in figure 8 . This closed fluid loop is very similar to the suggested ASHRAE Standard 93-77 configuration for glazed collectors but with several modifications to accommodate the more restrictive ASHRAE Standard 96-1980 test requirements for unglazed collectors. The test loop is capable of maintaining fluid temperatures to within $\pm 0.02^{\circ} \mathrm{C}$ $\left(0.036^{\circ} \mathrm{F}\right)$ at the inlet of the collector during a one minute test interval and maintaining the fluid flow rate through the collector to within \pm 0.9 percent. Major differences between the unglazed collector test loop and a typical ASHRAE Standard 93-77 closed loop configuration include:

\section{a. the capability of maintaining the collector fluid inlet temperature} below ambient temperature $\left(t_{f, i}<t_{a}\right)$;

b. the capability of delivering high fluid flow rates $0.126-0.504 \mathrm{l} / \mathrm{s}$ (2 to $8 \mathrm{gpm}$ ); and

c. the capability of resolving small temperature differences $\pm 0.03^{\circ} \mathrm{C}$ $\left(0.054^{\circ} \mathrm{F}\right)$ between the collector inlet and outlet.

The fluid test loop was designed to operate at subambient temperatures in order to obtain collector thernal performance at negative values of $t_{m}-t_{a}$ and $\left(t_{f}, i^{-t}\right) / G$ as required in ASHRAE Standard 96-1980. The fluid circulating in the test loop can be cooled below ambient air temperature using liquid-toliquid heat exchangers and chilled-water provided by a secondary loop. The two heat exchangers have different thermal capacities and can be connected singly or in tandem as required to meet the thermal load imposed by the test collector.

Most unglazed collectors operate at high fluid flow rates. Consequently, the fluid test loop was designed to operate at flo: rates from $0.126-0.504 \mathrm{l} / \mathrm{s}$ ( 2 to $8 \mathrm{gpm}$ ) typically eight times greater than the flow rate for glazed collectors of comparable area. The pump, hydronic system, and flow transducers were selected to accommodate the range of flow rates.

Because of these high fluid flow rates, unglazed collectors experience a small temperature rise, $\Delta t$; for a single collector module typically $1-2^{\circ} \mathrm{C}$. In order 


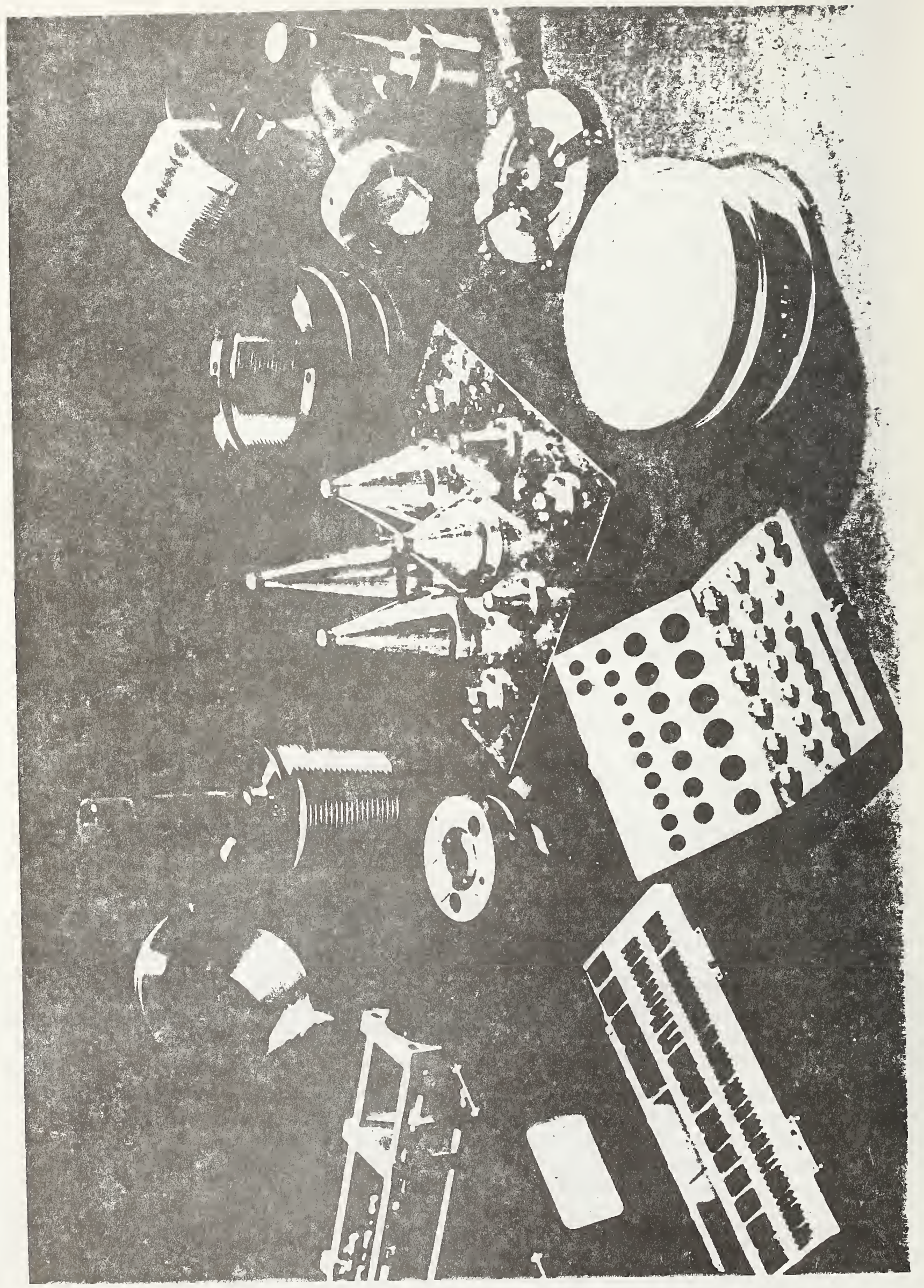




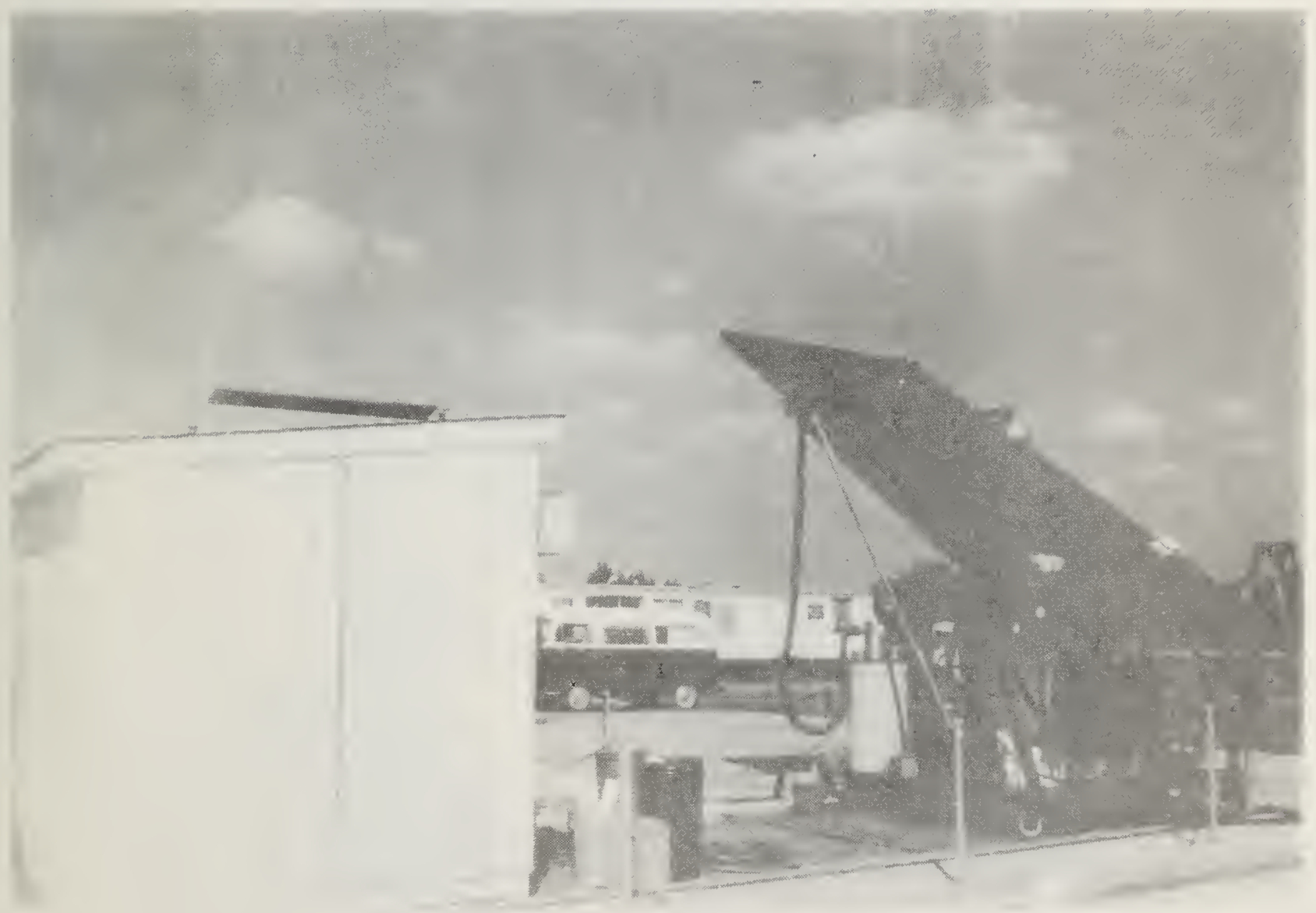

figure 4. View of the unglazed collector test facility showing the fluid loop, test stand, and instrumentation building during outioor testing. 



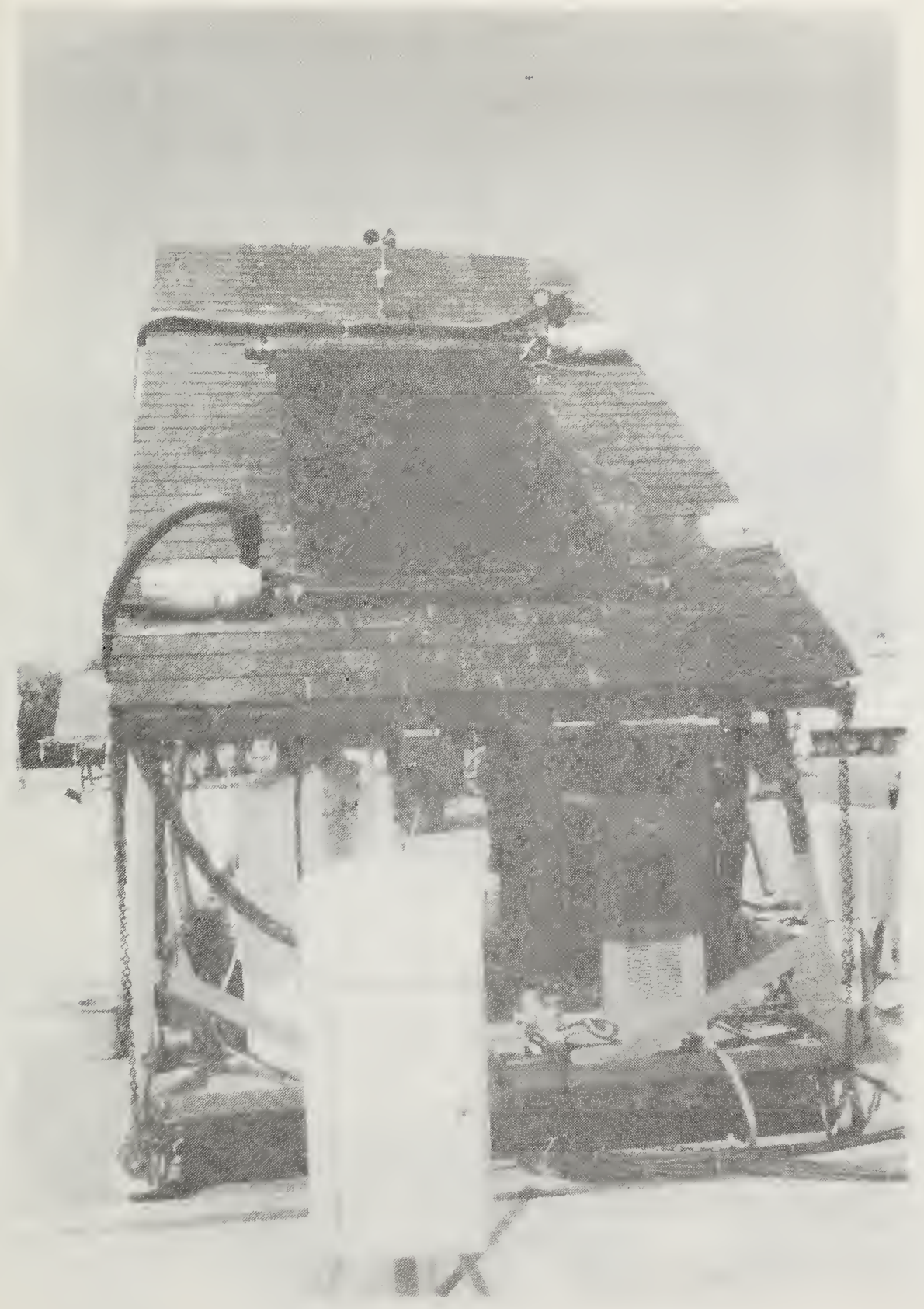

Firure 5. View of the unglazed collector test stand while perforning outdoor tests upon collector 1 . 


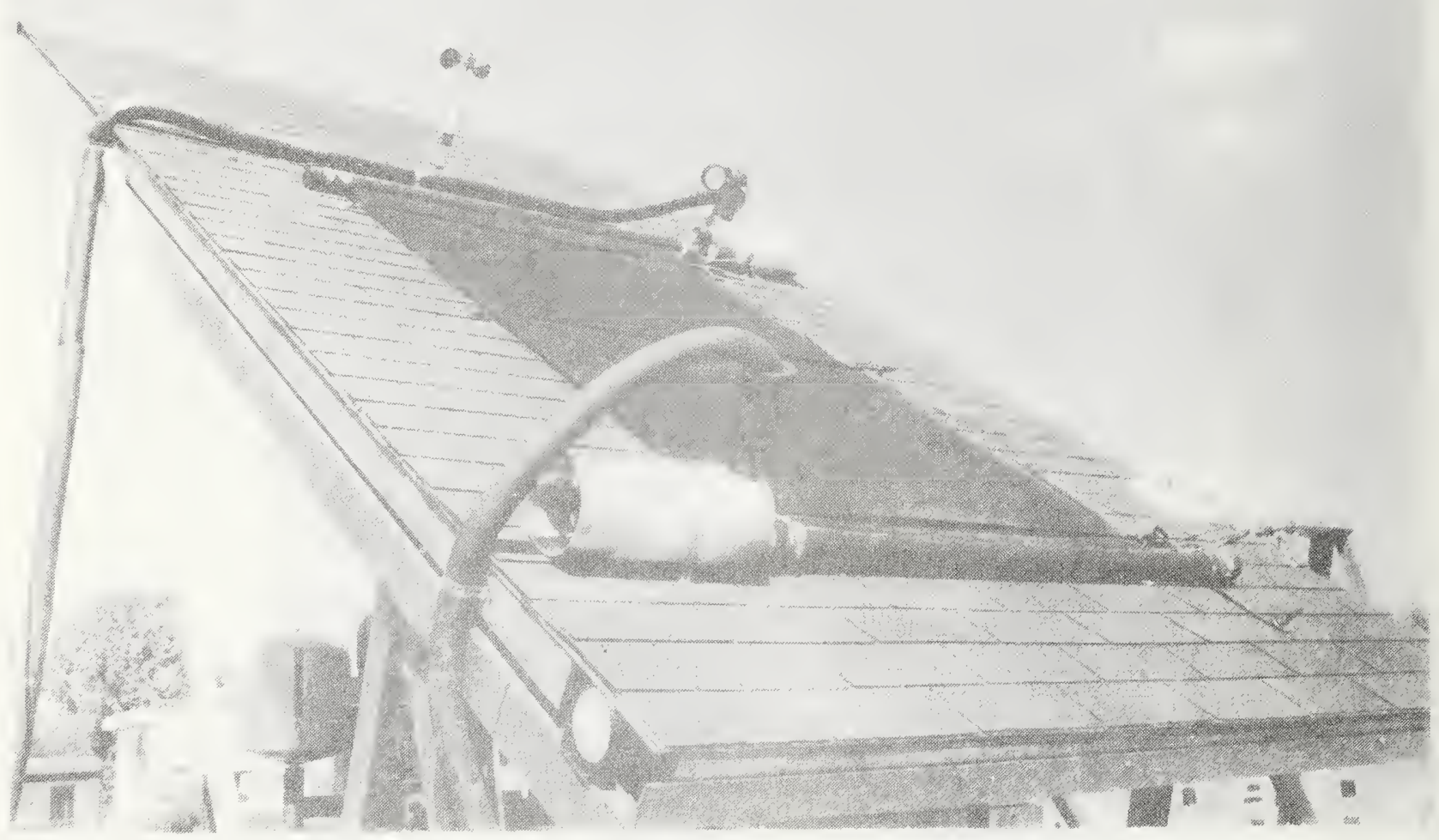

Figure 6. Close up view of collector 1 during outdoor tests showing the simulated roof test bed and temperature measurement sections at the collector fluid inlet and outlet. 


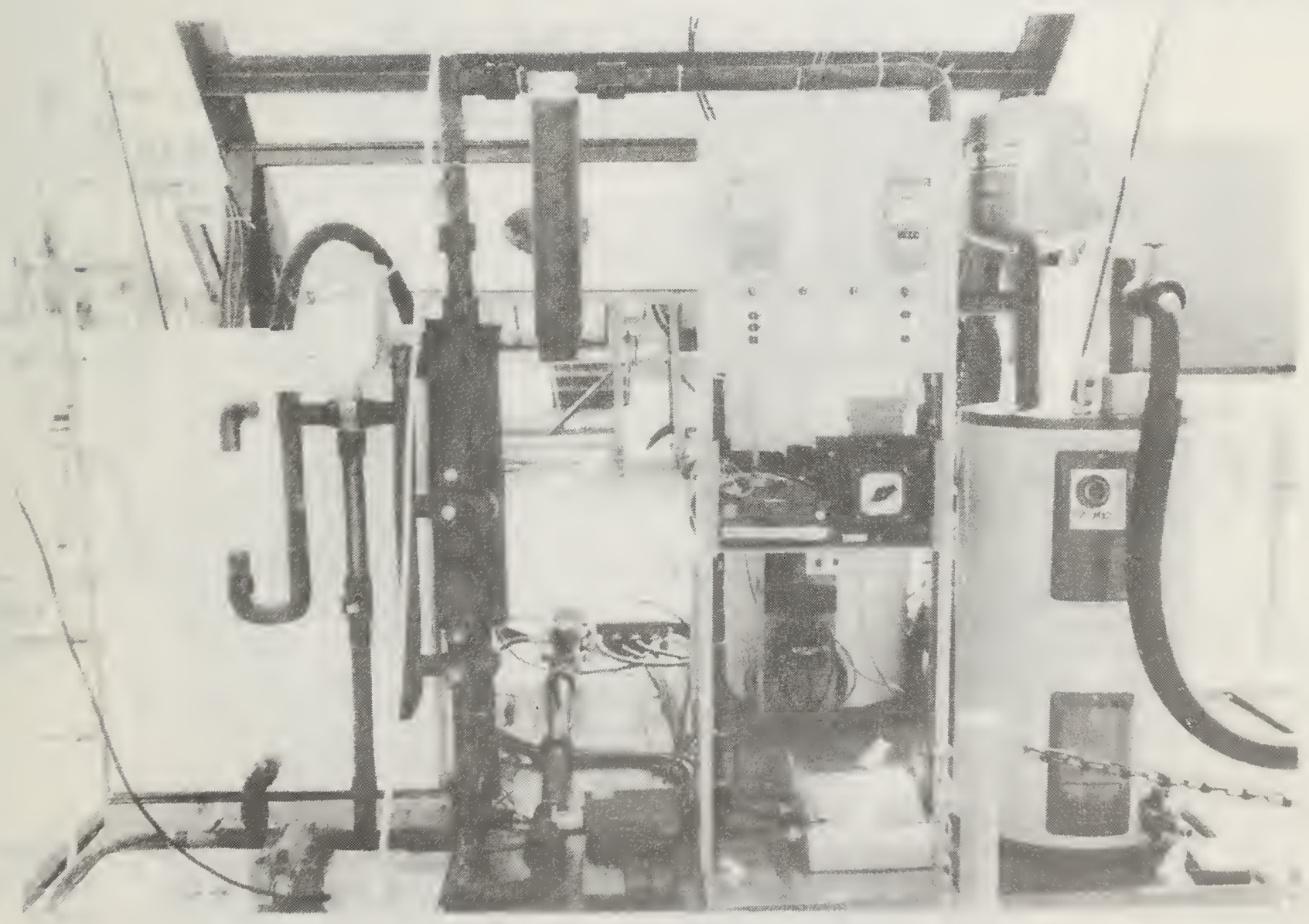

Figure 7. View of the fluid test loop mounted upon the test stand base. 


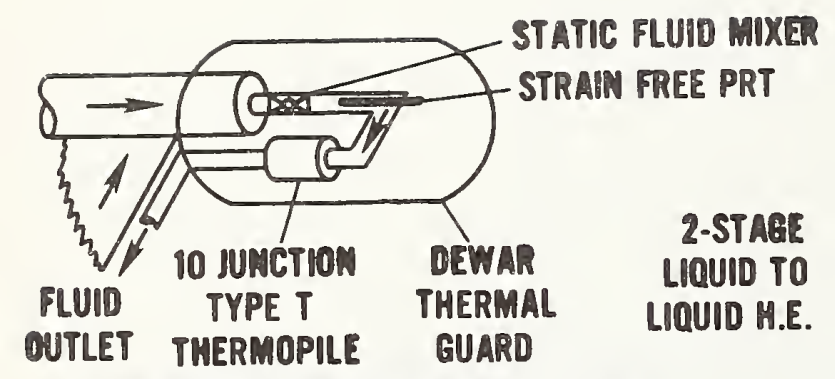

\section{TEMPERATURE MEASUREMENT SECTHON}

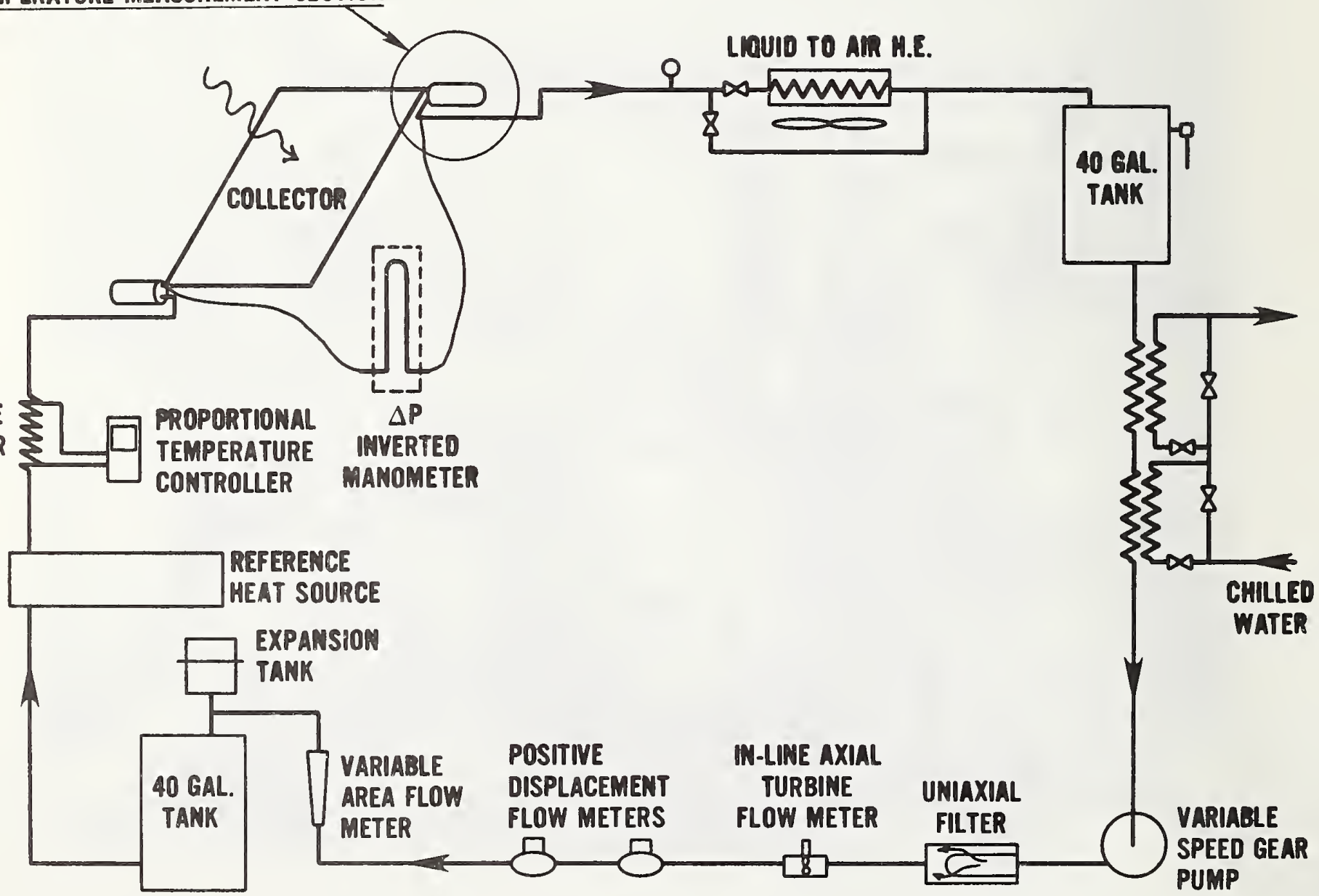

Figure 8. Schenatic of the fluid test loop. 


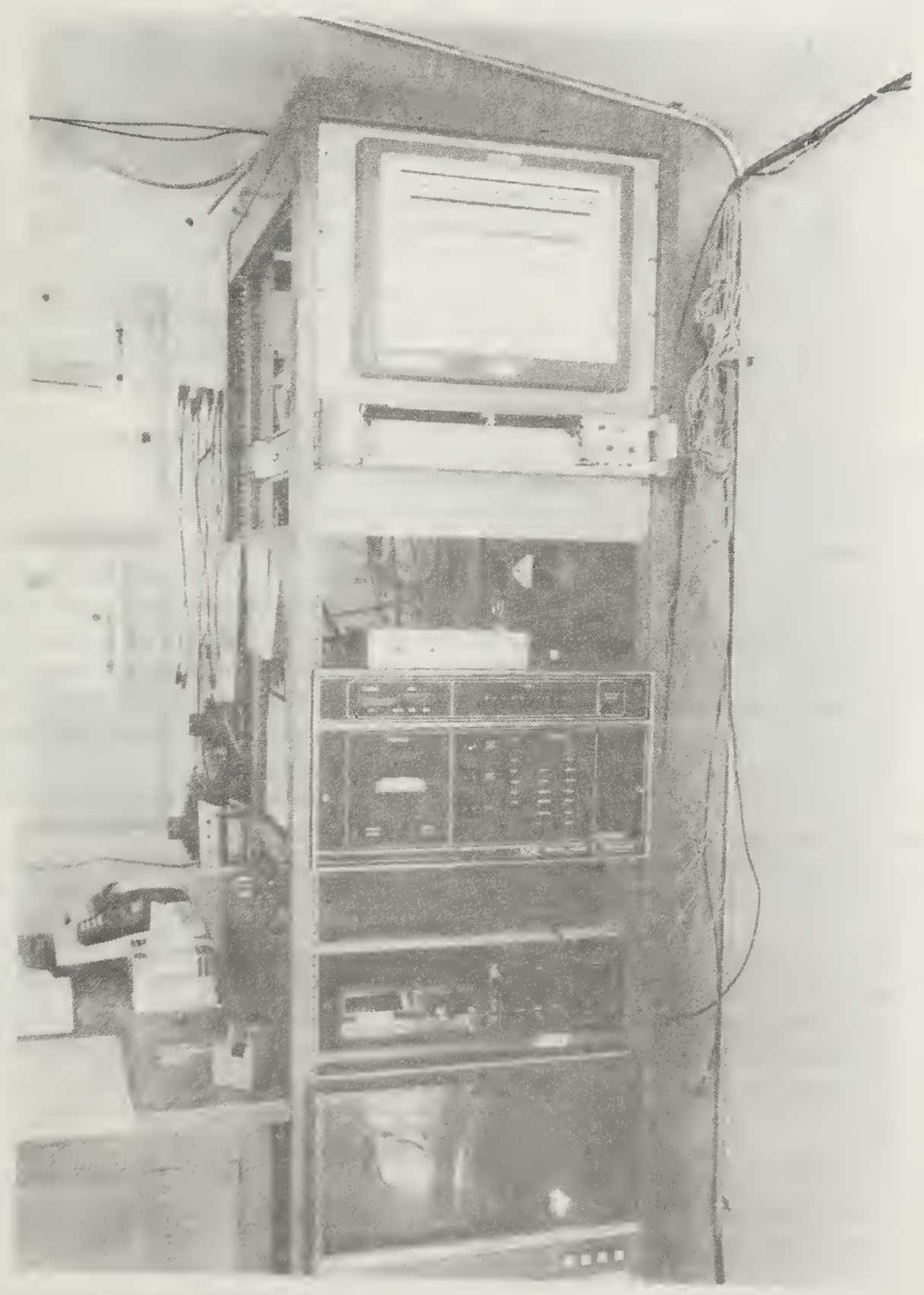

Figure 9. View of test facility instrumentation. 
to minimize the uncertainty in the $\Delta t$ measurement the apparatus must be able to resolve small temperature differences on the order of $\pm 0.01^{\circ} \mathrm{C}\left(0.018^{\circ} \mathrm{F}\right)$ as specified in ASHRAE Standard 96-1980. In practice the facility described is capable of resolving temperature differences with an uncertainty of $\pm 0.03^{\circ} \mathrm{C}$ $\left(0.054^{\circ} \mathrm{F}\right)$ under "steady-state" conditions. The $\pm 0.03^{\circ} \mathrm{C}$ resolution is a combination of the ability to stabilize the collector inlet fluid temperature and the ability to measure small temperature differences.

Stabilization of the collector inlet fluid temperature is attained through a combination of techniques. The fluid test loop is well insulated. Two $153 \ell$ ( 40 gal) tanks located at the collector supply and return provide a large thermal mass to buffer temperature fluctuations within the loop. The tanks were designed to be well mixed. Under average outdoor test conditions, the tanks dampen inlet temperature fluctuations to less than $\pm 0.02^{\circ} \mathrm{C}\left(0.03^{\circ} \mathrm{F}\right)$ over a one minute test interval. During indoor testing, greater temperature stability was possible with fluctuations less than $\pm 0.01^{\circ} \mathrm{C}\left(0.018^{\circ} \mathrm{F}\right)$ observed over a typical test interval.

Temperature measurement sections were constructed to measure the bulk fluid temperatures at both the collector inlet and outlet and the difference in fluid temperature between the collector inlet and outlet. One of the temperature measurement sections is illustrated in figure 8. Each temperature measurement section is thermally insulated with a wide-mouth vacuum dewar capped with $7.5 \mathrm{~cm}$ ( 3 in) of foam insulation. The dewar contains and thermally guards the platinum resistance thermometer (PRT) and the 10-junction type-T thermopile sensor. Each PRT is strain-free, has a time response of three seconds, and was calibrated at NBS to within an accuracy of $0.005^{\circ} \mathrm{C}$ $\left(0.01^{\circ} \mathrm{F}\right)$. The thermopile has a time response of $0.6 \mathrm{sec}$. It was calibrated at NBS and found to be capable of resolving temperature differences of $\pm 0.02^{\circ} \mathrm{C}$ $\left(0.036^{\circ} \mathrm{F}\right)$. The thermopile was constructed to be capable of monitoring average fluid temperature by using individual thermal wells for each of the 10junctions, distributed across the fluid stream. Static fluid mixers were placed upstream of the temperature sensors to ensure proper measurement of bulk fluid temperature. During testing, the PRT and thermopile $\Delta t$ measurements were cross checked for accuracy and temperature stability. If the agreenent was within $0.03^{\circ} \mathrm{C}\left(0.054^{\circ} \mathrm{F}\right)$ over a test interval, the $\Delta t$ measurement was considered valid. Before and after a series of experiments, the PRi calibrations were checked at the triple point of water $\left(0.01^{\circ} \mathrm{C}\right)$ by removing the sensors and inserting them into a Triple Point Cell.

\section{Instrumentation}

The data taken during testing were sampled and logged at one minute intervals by an automatic data acquisition systen shown in figure 9. Critical measurements such as solar irradiance, temperature difference across the collector, and wind speed were also continuously monitored using strip chart recorders. The prinary measurements and transducers monitored by the data acquisition system include: 
Measurement

Temperature

Collector Inlet and outlet

Ambient Air

Flow Rate

Radiation

Solar

Infrared

Wind Speed

\section{Transducer}

-10 Junction Type-T Thermopile -100 Ohm Strain Free Platinum Resistance Thermometers

-100 Ohm Platinum Resistance Thermometer Contained Within an Aspirated Radiation Shelter

-In Line Axial Turbine Meter -Positive Displacement Meters with an Eccentric Woble Disc

-Pyranometer PSP

-Pyrgeometer PIR

-3 Cup Wind Anemometer

Low Threshold with DC Generator

-Birams Pattern Vane Anemometer

The platinum resistance thermometers (PRT) were mutually connected in series with a 1 ma constant current source and a 100 ohm NBS-type precision resistor. The data acquisition system measured the voltage drops across each individual PRT and the precision resistor. The measured PRT voltage drops were then ratioed against the precision resistor voltage drop to determine the PRT resistances. PRT resistance-temperature relationships were then applied to determine the measured temperatures.

The test loop fluid flow rates were continously monitored using three flowmeters an in-line axial turbine meter and two positive displacement meters as shown in figure 8 . Each of the flowmeters has a digital output which was totalized over a one minute test interval to determine an average flow rate. Redundent flow meters were used to ensure the accuracy of flow measurement. In addition to the required straight lengths of pipe upstream and downstream of the turbine meter, a uniaxial filter was used upstream to eliminate flow swirling and properly condition the fluid. All three flowmeters and the uniaxial filter were periodically removed in tandem and calibrated. A visual flowmeter is located downstream of the three digital flowmeters. The visual flowmeter, or rotameter, functions as a coarse flow indicator and sight glass for determining whether air is trapped within the system. 


\section{EXPERIMENTAL TESTS}

Two unglazed flat plate liquid-heating collectors were tested according to both the modified BSE procedure and ASHRAE Standard 96-1980. The two collectors are described in table 1 and illustrated in figure 10. Collector 1 is an extruded polyolefin absorber impregnated with carbon black and collector 2 is a copper, tube and fin absorber with a high temperature black lacquer coating. The collectors tested were mounted against a rear-insulated asphalt shingle surface attached to the collector test stand. The sinulated roof surface can be seen in figure 6 .

During the $B \mathrm{SE}$ indoor thermal loss tests, shown in figures 11 and 12 , axial-fan wind simulators were used to simulate average wind speeds of 0 , 2.1 , and $3.6 \mathrm{~m} / \mathrm{s}(0,4.6,8.0 \mathrm{mi} / \mathrm{hr})$. The collectors were oriented horizontally with the axial fans blowing longitudinally along the collector plane. A vane anemometer was used to measure the air velocity of the simulated wind at $20 \mathrm{~cm}$ (3.93 in) increments across the collector midsection at $1 \mathrm{~cm}(0.4 \mathrm{in})$ above the surface. The air velocity reading at each location was obtained by integrating the air flow over a 30 second interval. As many as 13 readings were taken during a single run in order to determine an average wind speed. During a typical measurement sequence, wind speed uniformity ranged \pm 9 percent. To determine an average absorber plate surface temperature during the thermal loss tests, thermocouples were attached to the absorber surface. The thermocouples were positioned transverse across the collector midsection and located on and between the fluid risers.

During outdoor testing, shown in figure 5, the BSE optical efficiency, $n_{0}$, ASHRAE instantaneous thermal efficiency, and incident angle modifier were determined. The collectors were mounted upon a fixed, south-facing test stand and adjusted for normal incidence at solar noon. The ASHRAE thermal efficiency and BSE optical efficiency angle modifier data were obtained over solar noon at normal incidence $\pm 4^{\circ}$. Data to compute the incident angle modifier $\left(K_{\alpha \tau}\right)$ were obtained over the day as the sun tracked across the fixed, south-facing collector. Collector theral performance was tueasured at various angles of incidence both before and after solar noon to determine values of $K_{\alpha \tau}$. The outdoor wind speed was monitored using a cup anamometer mounted on the collector plane as shown in figure 6 . 
Table 1

\begin{tabular}{|c|c|c|}
\hline & Collector 1 & Collector 2 \\
\hline Manufacturer ${ }^{1}$ & Fafco & Terra-Light \\
\hline $\begin{array}{l}\text { Collector Area } \\
\text { Absorber Material }\end{array}$ & $\begin{array}{l}1.28 \mathrm{~m} \times 2.31 \mathrm{~m} \\
\text { Polyolefin }\end{array}$ & $\begin{array}{l}0.863 \mathrm{~m} \times 2.30 \mathrm{~m} \\
\text { Copper }\end{array}$ \\
\hline Flow Configuration & Parallel Risers & Parallel Risers \\
\hline Coating & $\begin{array}{l}\text { Carbon Black in } \\
\text { Polyolefin }\end{array}$ & Black Lacquer \\
\hline Solar Absorptance $(A M=1.5)^{2}$ & 0.96 & 0.95 \\
\hline I.R. Emittance $\left(25^{\circ} \mathrm{C}\right)^{3}$ & 0.92 & 0.89 \\
\hline $\mathrm{F}^{\prime}$ & 0.81 & 0.87 \\
\hline $\mathrm{F}_{\mathrm{R}}$ & 0.80 & 0.85 \\
\hline
\end{tabular}

1 Identification of commercial products does not imply recommendation or endorsement by the National Bureau of Standards.

2 obtained from laboratory spectrophotometer measurements.

3 Determined knowing $\alpha$ and absorber plate temperature.

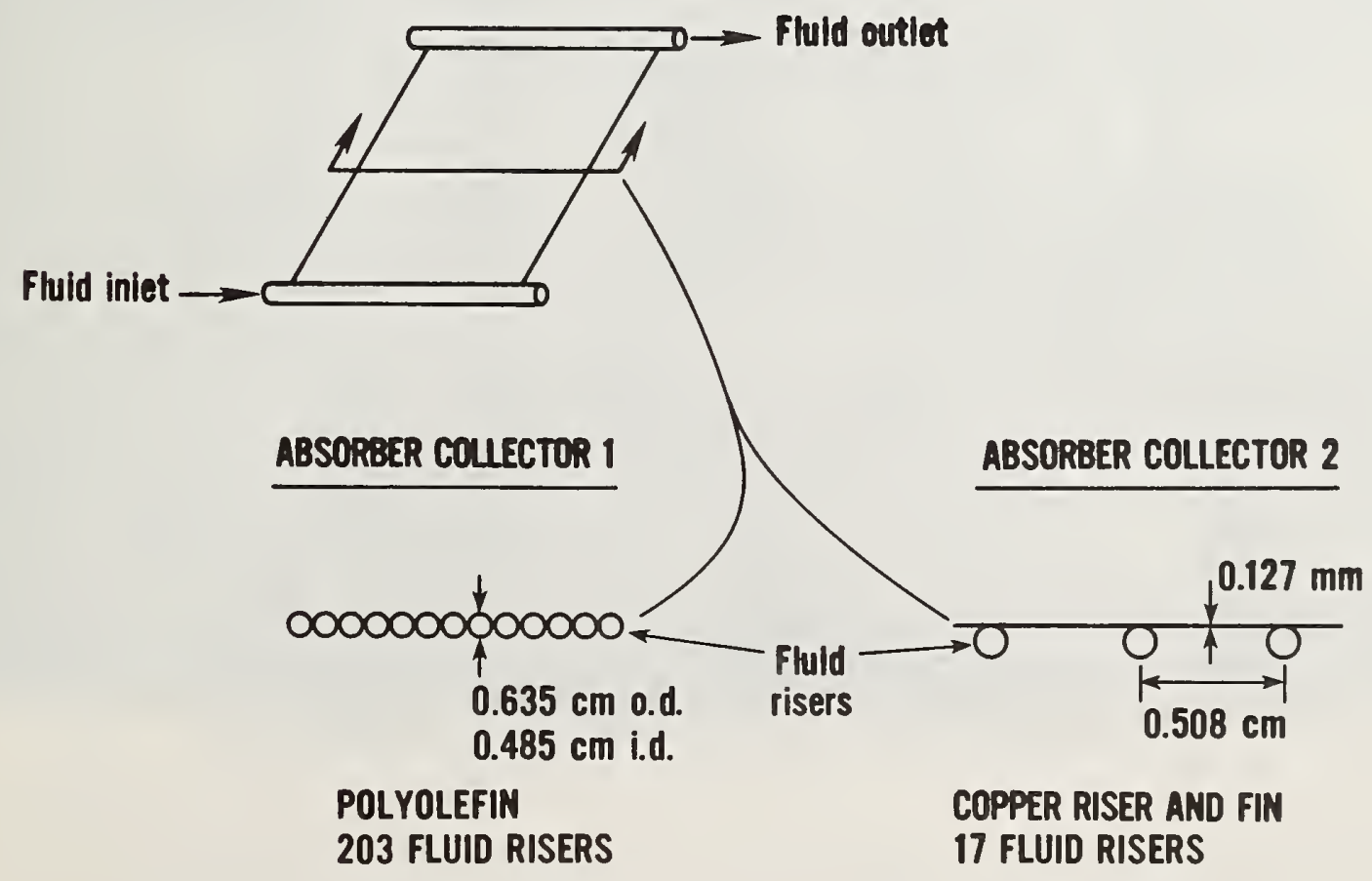

Figure 10. Cross-sectional view of unglazed collector 1 and 2 absorbers. 


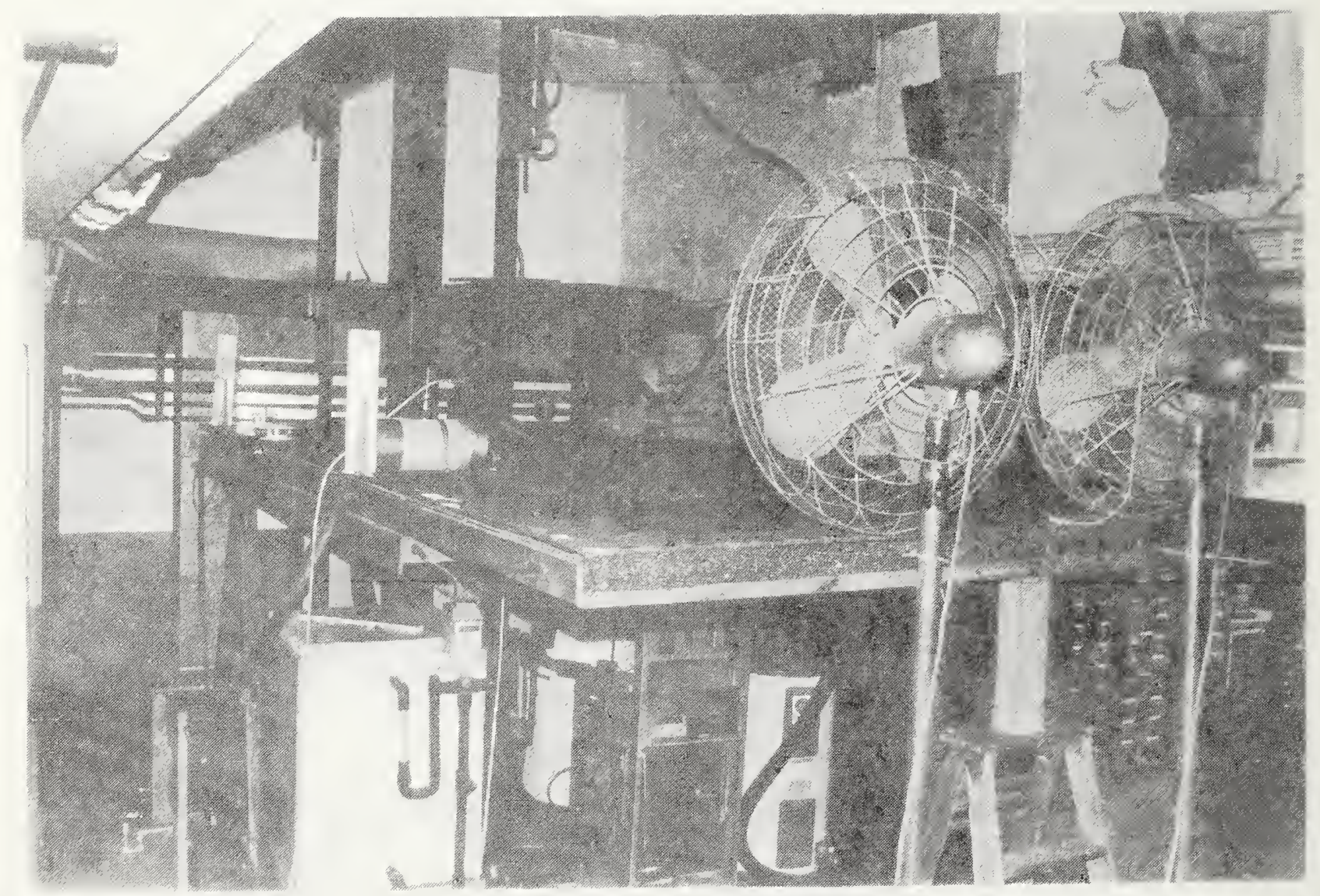

Figure 11. View of the unglazed collector test facility during indoor thernal loss tests with the axial fan wind simulators. 


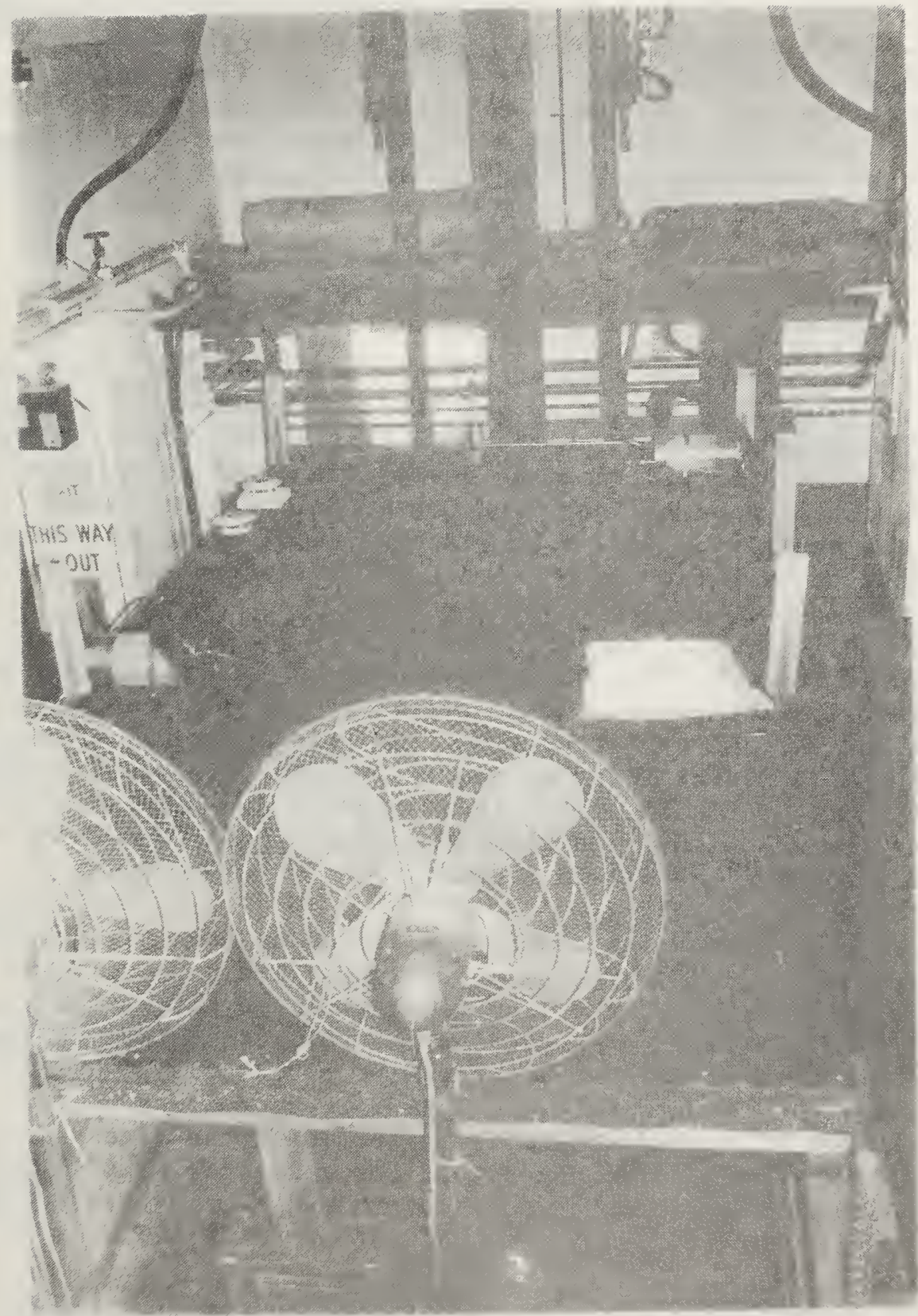

Figure 12. 'iop view of unglazed collector 1 during indoor thermal loss tests with the axial fan wind simulators. 
The BSE thermal curves for collectors 1 and 2 are presented.in figures 13 and 14 respectively. The collector overall thermal losses $\dot{Q}_{L}$ are plotted as a function of $t_{m}-t_{a}$ for average simulated wind speeds of $0,2.1$, and $3.6 \mathrm{~m} / \mathrm{s}(0,4.6,8.0 \mathrm{mi} / \mathrm{hr})$. Note that the curves cross over at $\mathrm{t}_{\mathrm{m}}-\mathrm{t}_{\mathrm{a}}=0$ and include negative thermal loss (i.e., a net gain) for negative $t_{m}-t_{a}$. This illustrates the fact that unglazed collectors readily gain thermal energy from the environment when operating at below ambient conditions. Environmental and operating conditions are noted on each figure. To compare the losses, the loss coefficient, $\mathrm{U}_{\mathrm{L}}$, was calculated for each collector using the relation

$$
\mathrm{U}_{\mathrm{L}}=\dot{\mathrm{Q}}_{\mathrm{L}} / \mathrm{A}\left(\overline{\mathrm{t}}_{\mathrm{p}}-\mathrm{t}_{\mathrm{a}}\right)
$$

where $\bar{t}_{p}$ is the average plate temperature of the collector. The loss coefficients at three wind speeds are plotted as functions of $\bar{t}_{p}-t_{a}$ in figure 15. The close agreement of the heat loss coefficients for the two collecturs is expected considering the nearly identical absorber optical properties and the consistent indoor environmental test conditions for both collectors. The change in slope of the zero-wind $U_{\mathrm{L}}$ curve is probably due to a laminar to turbulent transition in the free convection film coefficient.

Figures 16 and 17 show the outdoor test results used to determine the ASHRAE Standard 96-1980 instantaneous thermal efficiency as well as the data used to determine the BSE optical efficiency, $n_{0}$. In figure 16, the efficiency curve for collector 1 is a linear least square fit to the data, and in figure 17 , the efficiency curve for collector 2 is a second order least square fit. The encircled data in each figure indicate the outdoor data used to determine the BSE optical efficiency for each collector.

The environmental and operating conditions listed on each figure summarize the range of prevailing outdoor test conditions. The range of wind speeds reported for each data set in the figures is based on integrated wind speed averages from a cup anamometer mounted on the collector plane. Generally speaking, the range of prevailing outdoor wind speeds was lower for collector 1 than for collector 2 , especially for high values of $\left(t_{f}, i-t_{a}\right) / G$. This difference in prevailing wind speeds is reflected in the lower slope of the ASHRAE thermal efficiency curve determined for collector 1 . The influence of wind on the thermal performance is demonstrated clearly by the test data taken at values of $\left(t_{f, i}-t_{a}\right) / G$ near $0.03^{\circ} \mathrm{C} / \mathrm{w}^{\circ} \mathrm{m}^{2}\left(0.169^{\circ} \mathrm{F}-\mathrm{hr}-\mathrm{ft} \mathrm{t}^{2} / \mathrm{Btu}\right)$.

The right-hand group of data points in figure 16 was taken in calm conditions, whereas the comparable data group in figure 17 was taken with average wind speeds in the range $0.5-1.5 \mathrm{~m} / \mathrm{s}(0-3.35 \mathrm{mi} / \mathrm{hr})$. The increased scatter present in the latter data is striking. The influence of wind upon collector thernal performance increases with $\left(t_{f, i}-t_{a}\right) / G$ since collector thermal losses are directly a function of $\left(t_{f, i}-t_{a}\right)$. At high values of $\left(t_{f}, i-t_{a}\right) / G$ reached during testing, the influence of wind perturbations nearly precludes the attainment of quasi-steady-state test conditions, even though the average 


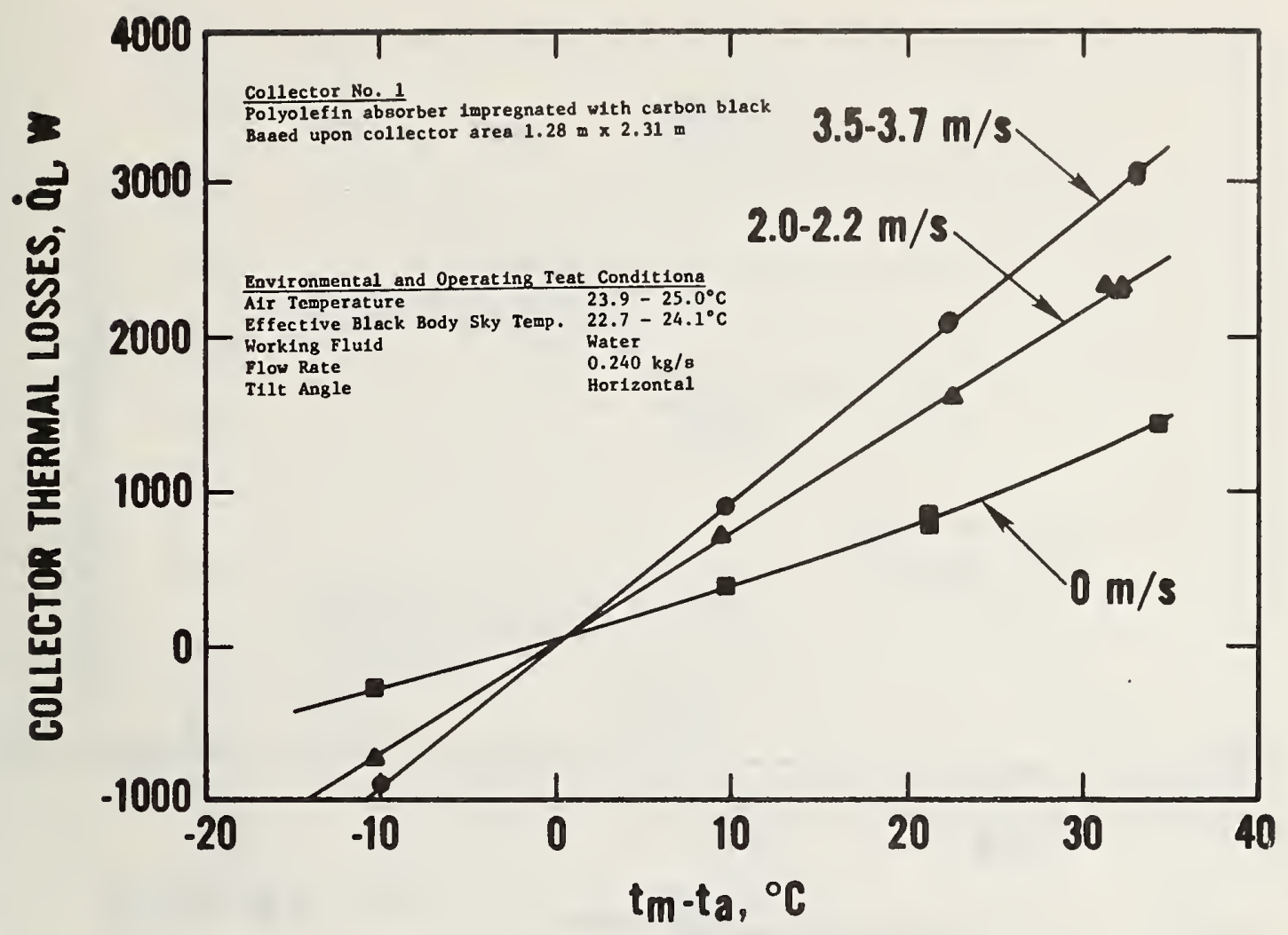

Figure 13. Collector 1 indoor thermal losses, $\dot{Q}_{L}$, versus the difference between collector mean fluid temperature, $t_{m}$, and ambient air temperature $t_{a}$.

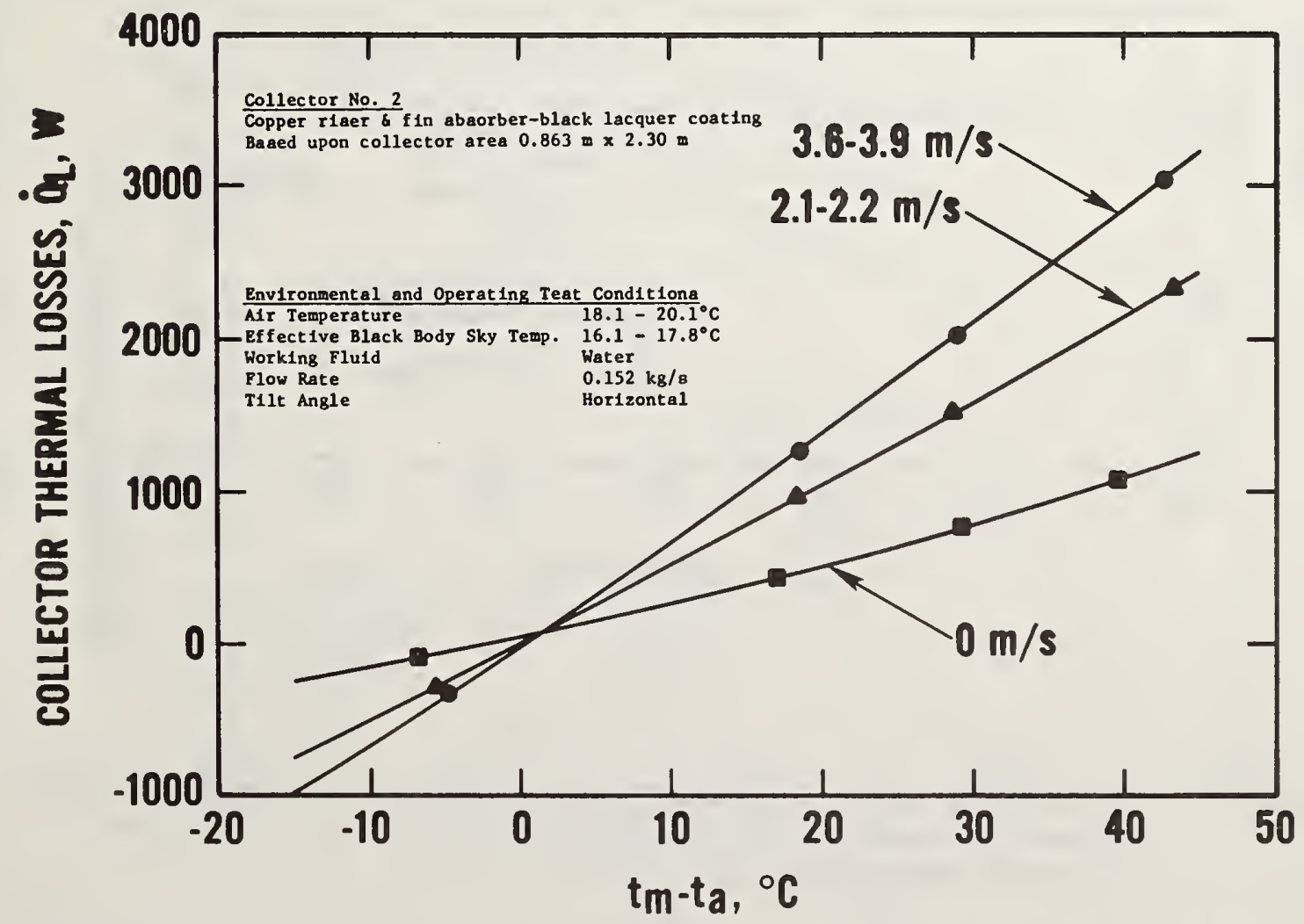

Figure 14. Collector 2 indoor thermal losses, $\dot{Q}_{L}$, versus the difference between collector mean fluid temperature, $t_{m}$, and ambient air temperature, $t_{a}$. 


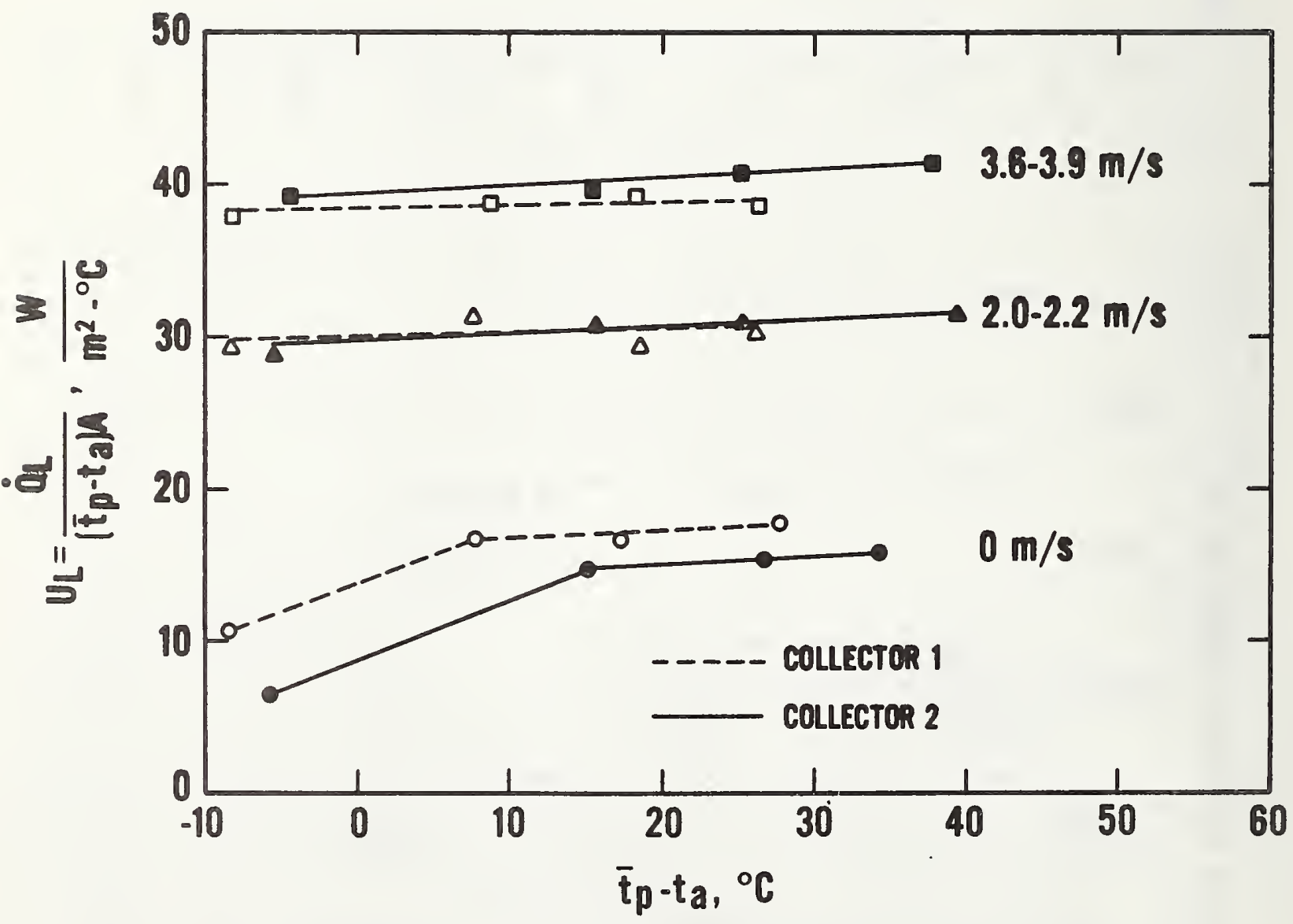

Figure 15. Collector 1 and 2 loss coefficients, $U_{L}$, versus the difference between collector mean plate temperature, $\bar{t}_{p}$, and ambient air temperature, $t_{a}$. 


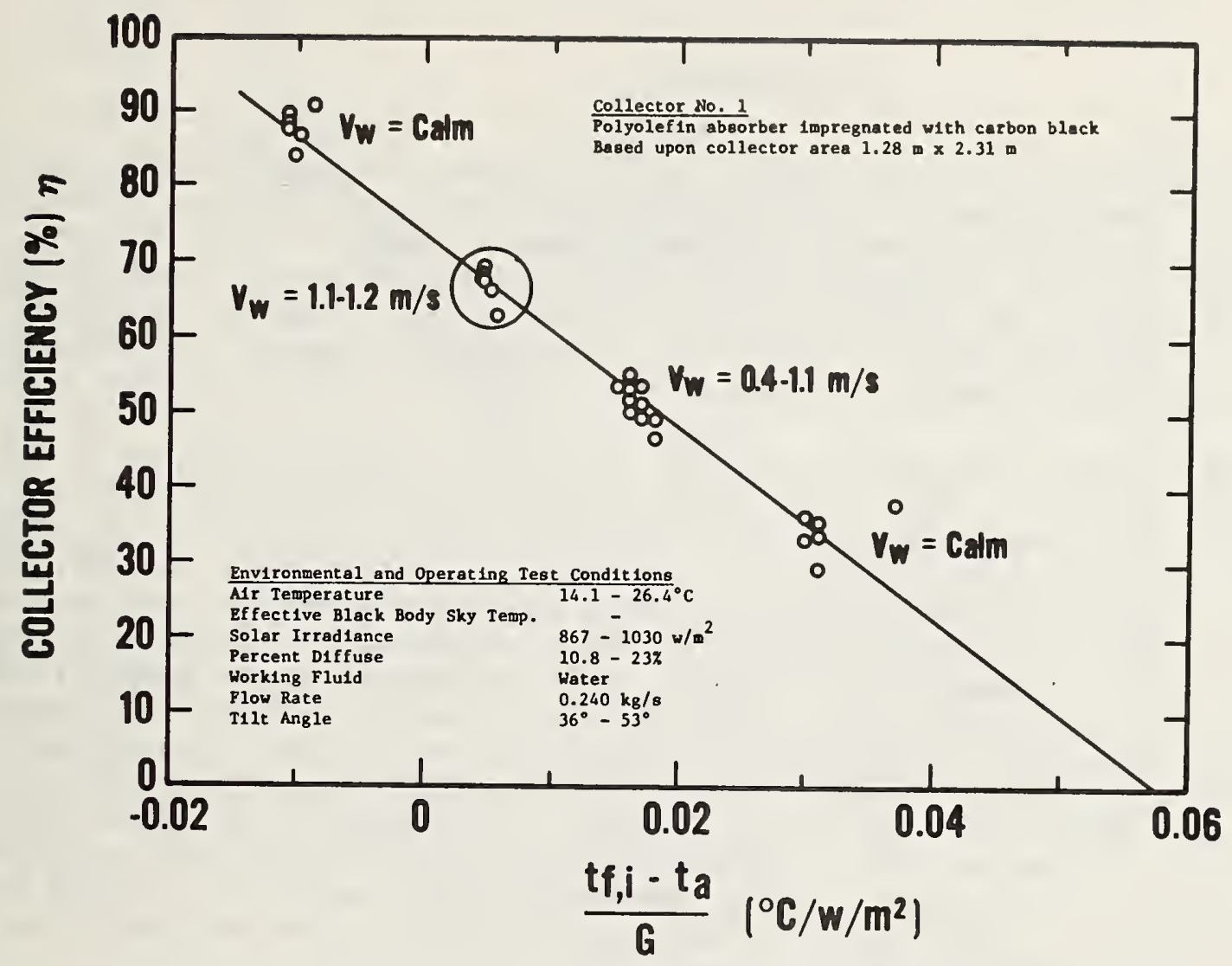

Figure 16. ASHRAE Standard 96-1980 efficiency curve and BSE $n_{0}$ data set (encircled) for collector 1 determined during outdoor testing.

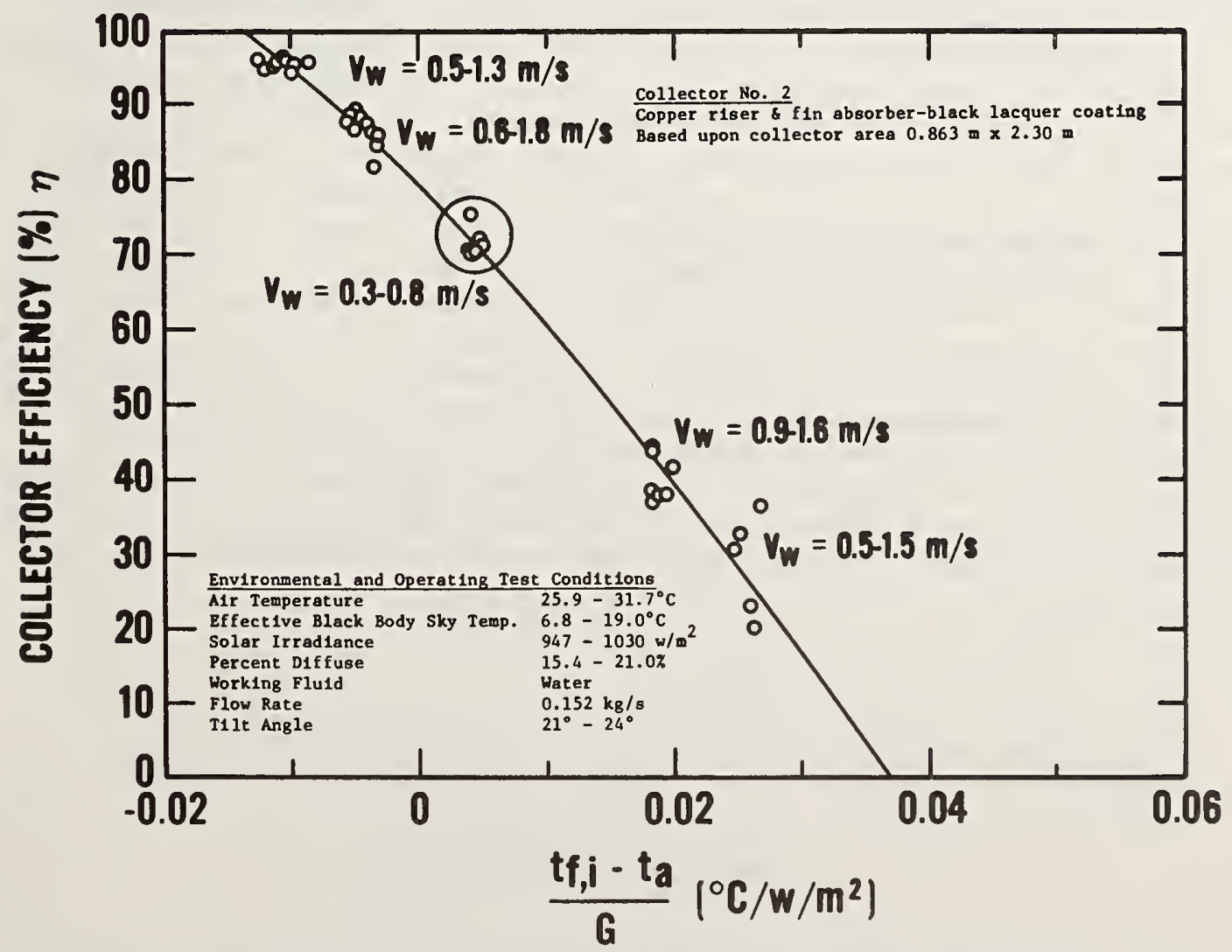

Figure 17. ASHRAE Standard 96-1980 efficiency curve and BSE $n_{0}$ data set (encircled) for collector 2 determined during outdoor testing. 
wind speeds were below the ASHRAE specified limit. No simple method was found to characterize the instantaneous wind speed and correlate it to the instantaneous thermal performance measurements in such a way as to reduce the data scatter. Based on the BSE investigation, it is felt that wind simulators could be used during outdoor testing. Although not attempted during this investigation, the use of wind simulators should result in more controllable and less transient wind conditions during the test.

The BSE thermal efficiency curves for the two collectors are shown in figures 18 and 19. The optical efficiencies were extrapolated from the ASHRAE thermal performance data encircled in figures 16 and 17 . The thermal losses were calculated for wind speeds of $0,2.1$, and $3.6 \mathrm{~m} / \mathrm{s}(0,4.6,8.0$ $\mathrm{mi} / \mathrm{hr})$. The solar irradiance used in the calculation was the average irradiance observed during the ASHRAE and BSE $n_{0}$ testing. For comparison, the calculated BSE thermal efficiency curves are presented in the ASHRAE format along with the ASHRAE curves. The influence of wind is clearly illustrated in the $3 S E$ curves. For collector 1, the BSE curve for zero wind agrees closely with the ASHRAE curve which represents test data obtained during calm wind conditions $(<0.5 \mathrm{mi} / \mathrm{hr}, 0.2 \mathrm{~m} / \mathrm{s})$. Likewise for collector 2 the agreement is good because the ASHRAE curve determined under wind speeds of $0.3-2.1 \mathrm{~m} / \mathrm{s}(0.6-4.6 \mathrm{mi} / \mathrm{hr}) \mathrm{falls}$ between the BSE 0 and $2.1 \mathrm{~m} / \mathrm{s}(0$ and 4.6 $\mathrm{mi} / \mathrm{hr}$ ) curve. In both cases the agreement between the BSE and ASHRAE curves is within the uncertainty of the efficiency curves.

The incident angle modifier curves, $\mathrm{K}_{\alpha \tau}$, for collectors 1 and 2 are shown in figures 20 and 21, respectively. Since the incident angle modifier is determined in an identical manner using the BSE or ASHRAE procedure, a single $K_{\alpha \tau}$ curve is presented for each collector. The collector incident angle modifier is plotted against the collector incident angle for data collected using a fixed south-facing test stand. The solid and open circles represent $K_{\alpha \tau}$ data obtained before and after solar noon, respectively. Typically, using a fixed test stand, collector thermal storage effects tend to skew $\mathrm{K}_{\alpha \tau}$ low before solar noon and high after solar noon. This degree of skewing or thermal lag effects is directly related to the collector time response and the transient nature of solar irradiance within the collector plane. The 99 percent step change time response of collectors 1 and 2 is very short, approximately one minute. Consequently, the hysteresis effect is negligible and is dorainated by random measurement uncertainties. This is illustrated by the near random distribution of $\mathrm{K}_{\alpha \tau}$ values before and after solar noon. For collector $1, K_{\alpha \tau}$ becomes non-linear at approximately $30^{\circ}$ whereas collector 2 is at best fit linear. The non-linearity of $k_{\alpha \tau}$ for collector 1 is most likely due to the convoluted absorber surface as shown in figure 10 . 


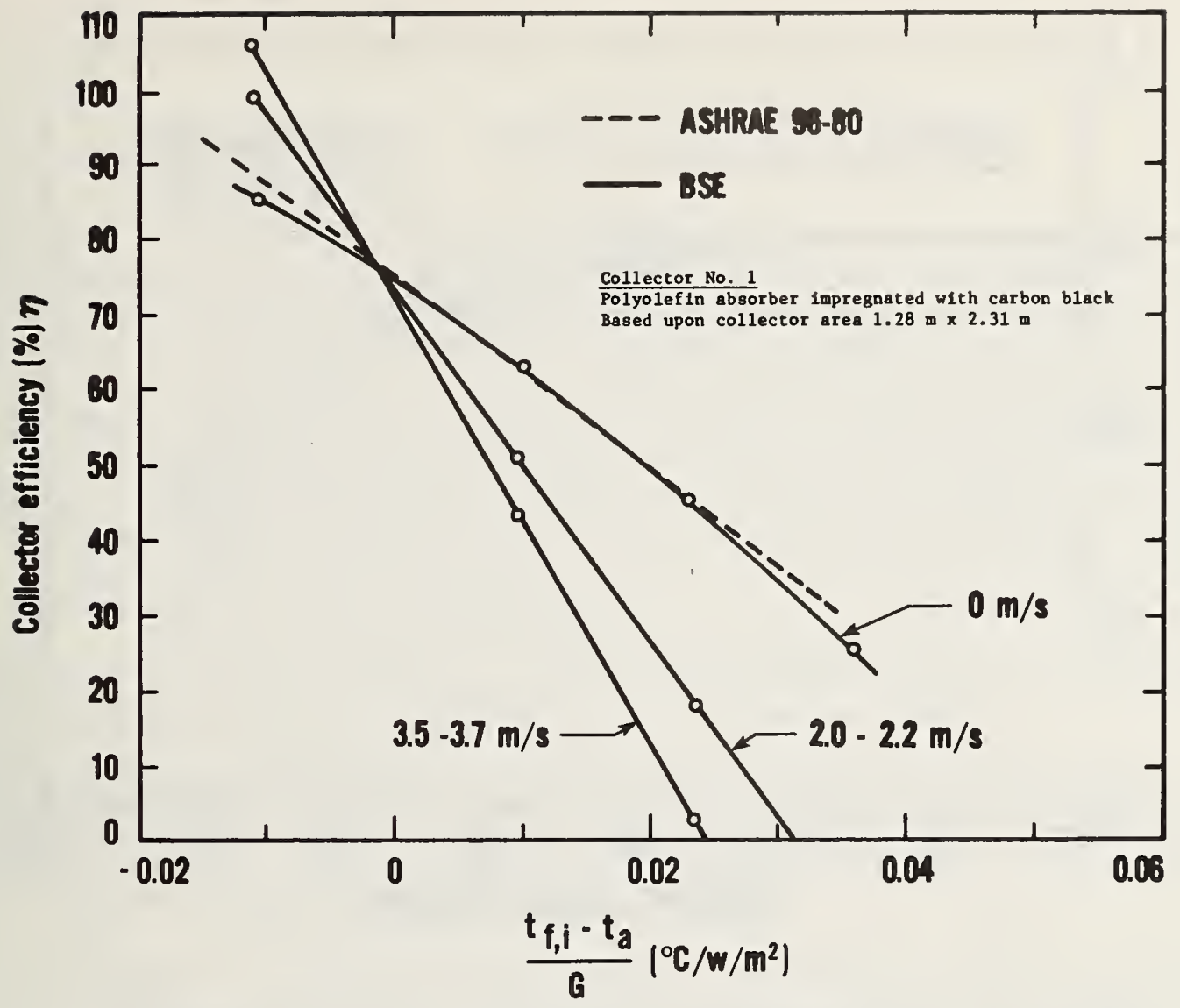

Figure 18. Comparison of ASHRAE Standard 96-1980 and modified BSE efficiency curves for collector 1 .

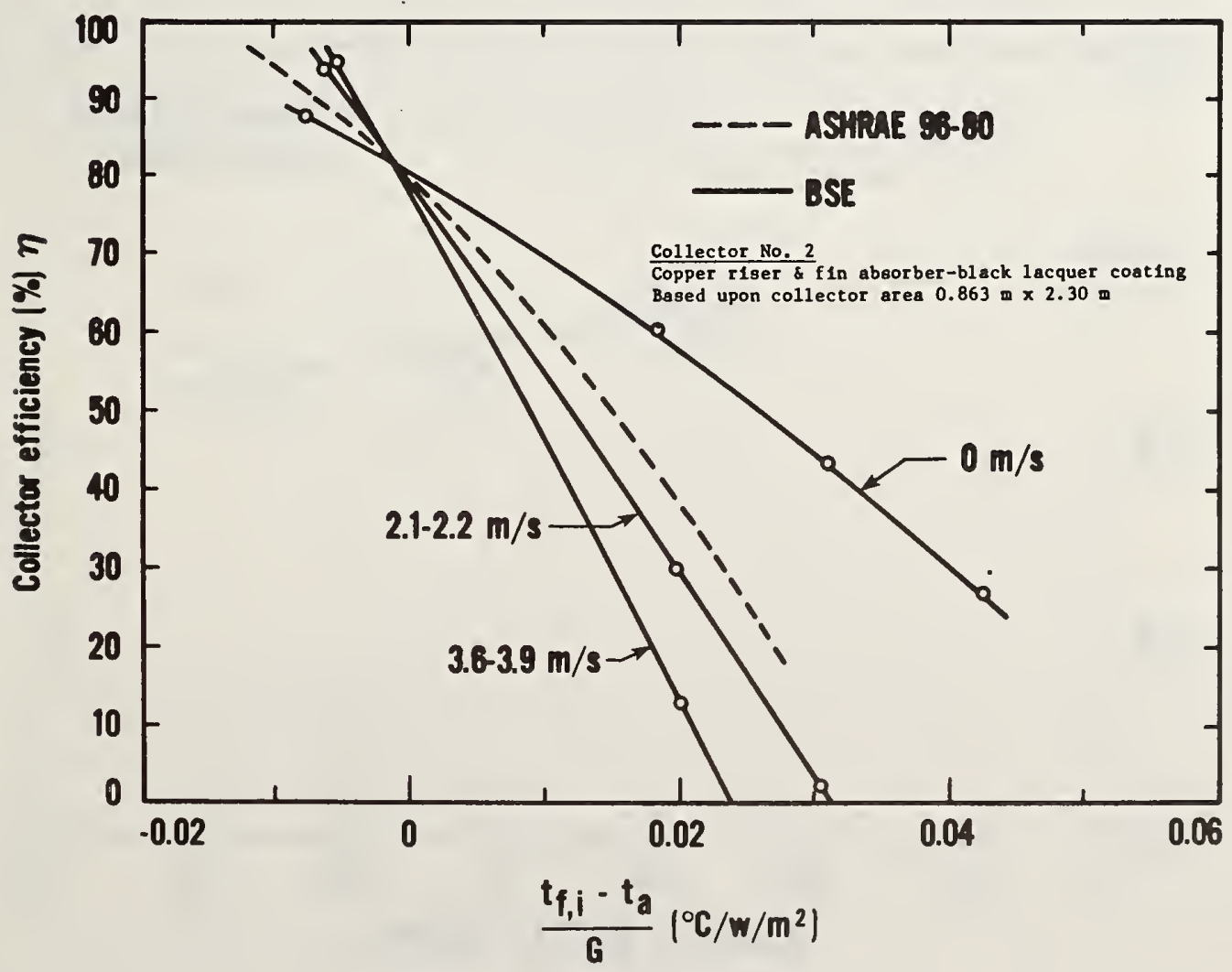

Figure 19. Comparison of ASHRAE Standard 96-1980 and modified BSE efficiency curves for collector 2 . 


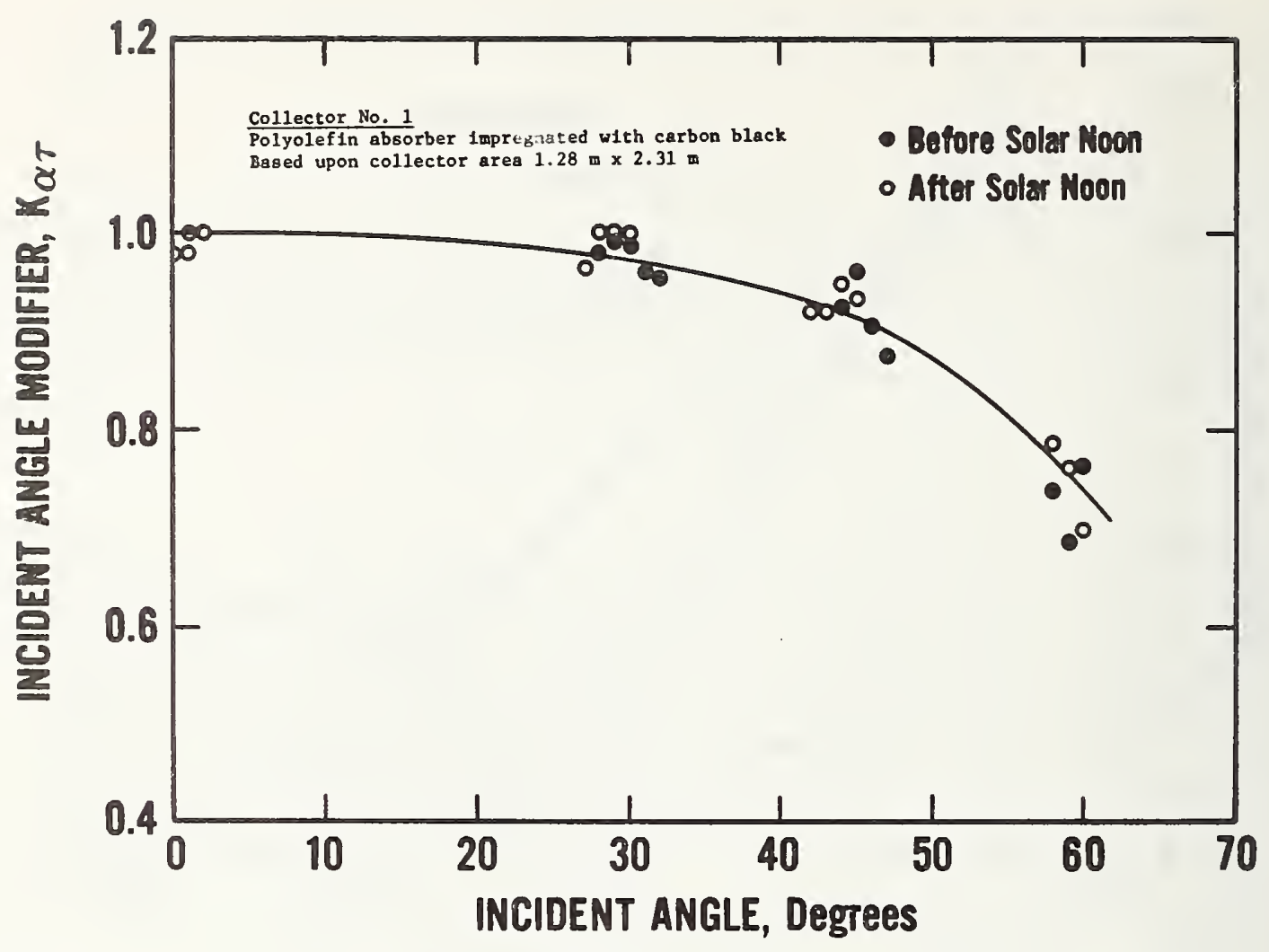

Figure 20. Incident angle modifier, $K_{\alpha \tau}$, for collector 1 .

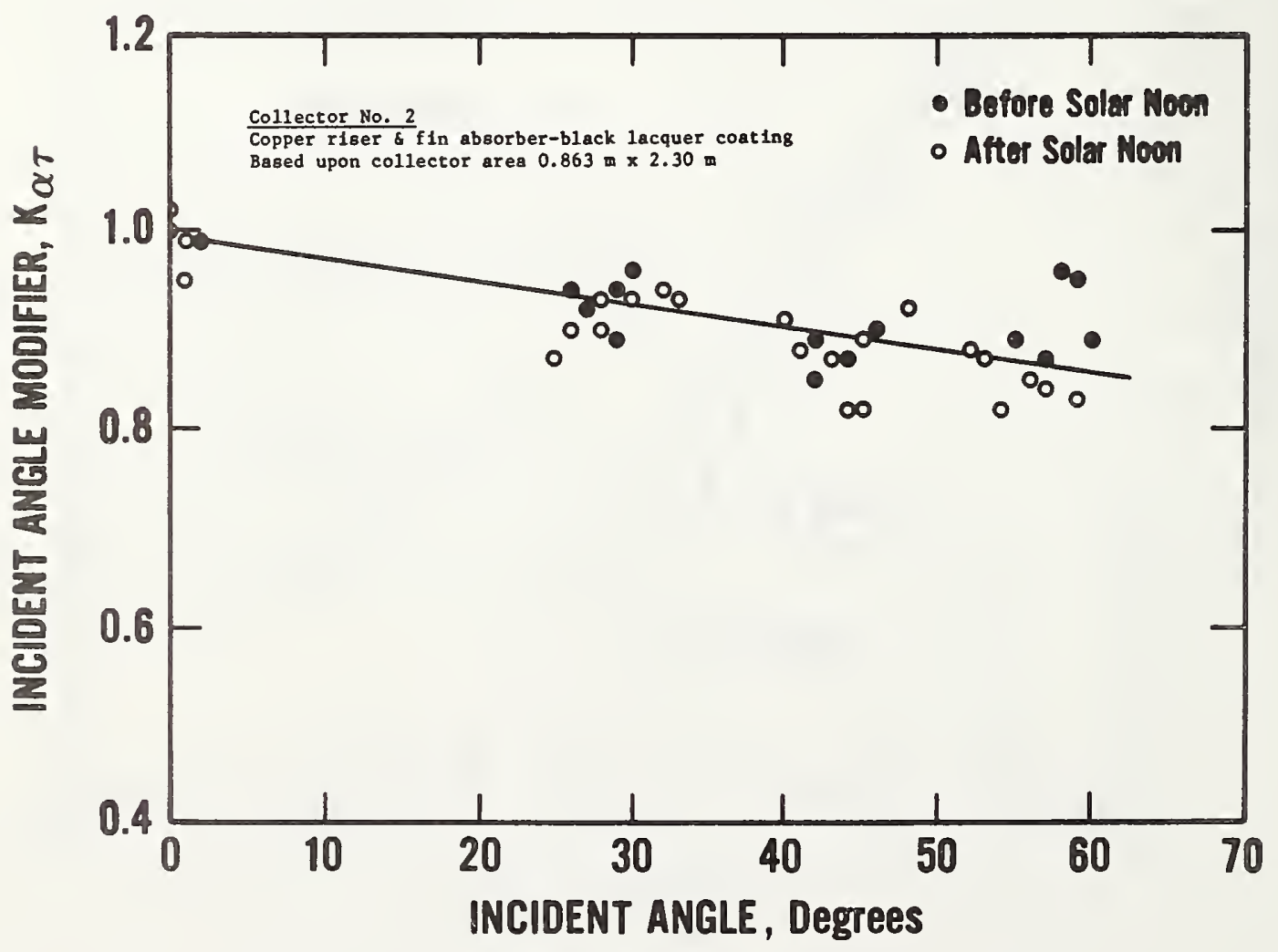

Figure 21. Incident angle modifier, $K_{\alpha \tau}$, for collector 2 . 


\section{SUMMARY AND CONCLUSIONS}

This paper has reviewed the modified BSE procedure and summarized the ASHRAE Standard 96-1980 Standard for testing unglazed solar collectors. An unglazed collector test facility was constructed and two unglazed collectors tested in accordance with both procedures. The BSE efficiency curves demonstrate the strong sensitivity of collector thermal performance with wind. The ASHRAE results illustrate the data scatter due to quasi-steady-state outdoor test conditions and due to measurement uncertainties associated with resolving small temperature differences across a collector. For the two flat plate liquid unglazed collectors tested, the differences between the BSE and ASHRAE Standard 96-1980 thermal efficiency curves were less than the uncertainty associated with the curves.

For testing unglazed collectors, the modified BSE technique is preferred over the ASHRAE Standard 96-1980 for the following reasons:

The $3 \mathrm{SE}$ procedure eliminates the large uncertainties in determining collector thermal performance associated with transient outdoor test conditions by determining steady-state collector thermal losses within a controlled laboratory environment.

The BSE procedure allows collector thermal performance to be determined under selected environmental conditions. Because of the environmental sensitivity of unglazed collectors it is essential that collector thermal performance be measured over a range of wind speeds and directions.

The BSE determination of the near normal incidence efficiency curve can be completed in less test time than normally required for ASHRAE Standard 961980. The combined indoor-outdoor BSE testing minimizes the dependence of tests upon outdoor environmental conditions. 


\section{REFERENCES}

1. "Methods of Testing to Determine the Thermal Performance of Unglazed Flat-Plate Liquid Type Solar Collector," ASHRAE Standard 96-1980, ASHRAE, 1791 Tullie Circle, N.E., Atlanta, GA 30329, 1980.

2. "Method of Testing to Determine the Thermal Performance of Solar Collectors," ASHRAE Standard 93-77, ASHRAE, 1791 Tullie Circle, N.E., Atlanta, GA 30329, 1980 .

3. BSE Guidelines and Directions for Determining the Usability of Solar Collectors, A. Solar Collector Efficiency Test, BSE, Kruppstrasse 5 , 4300 Essen 1, Federal Republic of Germany, May 1978.

4. Jenkins, J. P. and Hill, J. E., "Testing Flat-Plate Water-Heating Solar Collectors in Accordance with the BSE and ASHRAE Procedures," NBSIR 80-2087, August 1980.

5. Jenkins, J. P. and Hill, J. E., "A Comparison of Test Results for Flat-Plate Water-Heating Solar Collectors Using the BSE and ASHRAE Procedures," ASME Journal of Solar Energy Engineering, Vol. 102, No. 1 , pp 2-15, 1980 .

6. Jenkins, J. P. and Bushby, S. T., "Differences in Determining Collector Thermal Performance Between the BSE and ASHRAE Collector Test Procedures," National Bureau of Standards, Washington, D.C. 20234 , 1981, submitted for publication to the ASME Journal of Solar Energy Engineering. 
U.S. DEPT. OF COMM.

BIBLIOGRAPHIC DATA

SHEET (See instructions)
1. PUBLICATION OR REPORT NO.

NBSIR $82-2522$
2. Performinz Organ. Report Nod 3. Publication Date

May 1982

4. TITLE AND SUBTITLE

A Comparison of Unglazed Flat Plate Liquid Solar Collector Thermal Performance Using the ASHRAE Standard 96-1980 and Modified BSE Test Procedures

\section{AUTHOR(S)}

John P. Jenkins and Kent A. Reed

6. PERFORMING ORGANIZATION (If joint or other than NBS, see instructions)

7. Contract/Grant No.

MATIONAL BUREAU OF STANDARDS

DEPARTMENT OF COMMERCE

WASHINGTON, D.C. 20234

9. SPONSORING ORGANHZATION NAME AND COMPLETE ADDRESS (Street, City, StOTE, ZIF)

Division of Active Heating and Cooling

office of Solar Heat Technologies

U.S. Department of Energy

Washington, D.C. 20585

10. SUPPLEMENTARY NOTES

Document describes a computer program; SF-185, FIPS Software Summary, is attached.

11. ABSTRACT (A 200-word or less factual summary of most significant information. If document includes a significant bibliography or literoture survey. mention it here)

This paper reviews the BSE procedure and summarizes the ASHRAE Standard 96-1980 for testing unglazed solar collectors. The ASHRAE procedure consists exclusively of outdoor testing, whereas the BSE procedure requires a combination of outdoor and indoor testing (no irradiation) to determine the collector optical and thermal loss characteristics, respectively. Two unglazed flat plate liquid solar collectors were tested according to ASHRAE Standard 96-1980 and BSE procedures and the results compared. During the indoor BSE thermal loss tests blowers were used to simulate winds of 0-3.9 $\mathrm{m} / \mathrm{s}(0-8.72 \mathrm{mi} / \mathrm{hr})$ to investigate the wind effect upon collector thermal losses. The results demonstrate that the differences between the BSE and ASHRAE Standard 961980 thermal efficiency curves were less than the uncertainty associated with the curves.

12. KEY WORDS (Six to twelve entries; alphabetical order; capitalize only proper names: and separate key words by semicolons) ASHRAE Standard 96-1980; BSE; collector efficiency; unglazed collector

Order From Superintendent of Documents, U.S. Government Printing Office, Washington, D.C. 20402.

X] Order From National Technical Information Service (NTIS), Springfield, VA. 2216I

14. NO. OF PRINTED PAGES 34

15. Price 


